\title{
Physical-Chemical Characterization and Mineralogic Analysis of Hydrothermal Systems Located in the Coconuco and the San Juan Sectors in Cauca, Colombia
}

\author{
Darwin Augusto Torres-Ceron $\mathbb{D}^{1},{ }^{1}$ Carlos Daniel Acosta-Medina, ${ }^{2}$ \\ and Elisabeth Restrepo-Parra ${ }^{1}{ }^{1}$ \\ ${ }^{1}$ Laboratorio de Física del Plasma, Universidad Nacional de Colombia, Manizales, Colombia \\ ${ }^{2}$ Departamento de Matemáticas y Estadística, Universidad Nacional de Colombia, Manizales, Colombia \\ Correspondence should be addressed to Darwin Augusto Torres-Ceron; dtorresce@unal.edu.co
}

Received 10 January 2019; Accepted 10 March 2019; Published 12 May 2019

Academic Editor: John A. Mavrogenes

Copyright (c) 2019 Darwin Augusto Torres-Ceron et al. This is an open access article distributed under the Creative Commons Attribution License, which permits unrestricted use, distribution, and reproduction in any medium, provided the original work is properly cited.

\begin{abstract}
Hot springs of the volcanic zones are characterized for having high sulfur content in the form of sulphate and other ions resulting from chemical reactions. Sources with these types of elements are of great interest for the tourism and geothermal industry because of their highlighted properties which include therapeutic treatments, relaxation baths, agricultural applications, and preservation of flora and fauna among others. For these reasons, research oriented to carry out the characterization of these factors is of great importance to determine the availability of places with such characteristics. This work shows the characterization of 17 hot spring sources located in the Coconuco and San Juan sectors (Cauca, Colombia, South America). Water samples were taken in May 2017, and laboratory analyses were carried out by the Water Laboratory at Universidad Nacional de Colombia-Manizales, based on the Standard Methods (APHA-AWWA-WEF). Rock samples were taken in November 2017, and laboratory analyses were carried out by the GMAS ${ }^{+}$Laboratory (Bogotá, Colombia). The Piper, Stiff, and ternary (Giggenbach) diagrams were used for the classification of major ions. Mineralogy composition was determined through XRD and XRF. Results indicate that most sources are of the sulphated type according to the anions and of the calcium type according to the cations. In concordance with Giggenbach diagrams, most of the sources are immature waters and, despite their interaction with rocks, they have not achieved the equilibrium. Likewise, these sources are of heated vapor type and, considering that they consist of sulphated acid sources, it is not possible to evaluate the reservoir temperatures from $\mathrm{Na} / \mathrm{K}$ cations. The low $\mathrm{Ca}^{2+} / \mathrm{Mg}^{2+}$ ratio in the sources indicates the lack of direct migration of fluids and the high content of $\mathrm{Ca}^{2+}$ and $\mathrm{Mg}^{2+}$ regarding $\mathrm{Na}^{+}$and $\mathrm{K}^{+}$, which suggests that fluids possibly are mixed with cold waters rich in $\mathrm{Ca}^{2+}$ and $\mathrm{Mg}^{2+}$. From the mineralogic characterization, it was observed that volcanic rocks are composed of cristobalite and albite with $\mathrm{TiO}_{2}, \mathrm{Fe}_{2} \mathrm{O}_{3}$, and $\mathrm{CaO}$ traces and mineral sulfur. Metals like $\mathrm{Cr}$, considered in this case as contaminants, are found in low concentrations in rocks and are not detected in these waters.
\end{abstract}

\section{Introduction}

Sulfur is one of the main components in the volcanic zones being present in both liquid and vapor phases and either in the form of sulfur and/or sulphate [1]. The origin of sulfur is attributed to the degasification of magma or leaching of rocks, influencing the chemistry of thermal fluids [2]. Hot springs are characterized in their composition by the content of ions and trace elements which are dissolved due to chemical reactions, cation exchange, hydrolysis, natural processes, and redox processes among others, carried out during the water-rock interaction [2-4], which establish a thermal character $[5,6]$. These natural resources are of great relevance for the geothermal and tourism industry $[7,8]$, mainly in the development of spa and health tourism, keeping in mind that these natural resources have combined customs and traditions of many 
regional cultures over time $[8,9]$. According to the above, these applications have converted geothermal springs into an interesting field of research and works like this can serve as a basis for the development of future projects.

Several studies have been reported concerning thermal waters including King et al. [10] that applied ultraclean sampling methods to quantify traces of $\mathrm{Hg}$ (total $\mathrm{Hg}, \mathrm{MeH}$ ) and microbial biomass in thermal waters of the Yellowstone National Park in the United States. In that study, they used molecular methods to determine microbial communities. From these analyses, traces of $\mathrm{MeHg}$ between 1 and $10 \mathrm{ng} / \mathrm{g}$ and total $\mathrm{Hg}$ between 4.9 and $120 \mathrm{ng} / \mathrm{g}$ were found. Regarding the microbial mass, the presence of the Chloroflexi bacteria was observed in sources chemically different. Bucher et al. [11] studied a thermal source of the Muzhaerte River in Tianshan, Western China, which is used for balneological and spa purposes, due to its therapeutic properties. The elemental composition is dominated by $\mathrm{Na}, \mathrm{SO}_{4}, \mathrm{Cl}$, and $\mathrm{Ca}$ ions, since the reactions with granite and the leaching of halite dissolve the albite feldspar mineral in $\mathrm{H}_{2} \mathrm{SO}_{4}$. On the other hand, Cox et al. [12] conducted photosynthesis studies in 996 places in the hot springs of Yellowstone National Park, in the United States. The results showed temperature variations between 14 and $94^{\circ} \mathrm{C}$ and $\mathrm{pH}$ between 0.8 and 9.7, and it was observed that photosynthesis was favored at lower temperatures and $\mathrm{pH}$ below 6.5, attributing this behavior to the sulfur concentrations. Chandrajith et al. [13] examined 7 hot springs in Sri Lanka for determining the temperature of the deposits according to the chemical composition. The geothermal calculations showed high temperatures with 122 and $121^{\circ} \mathrm{C}$, and the samples with lower temperatures showed low concentrations of trace elements such as $\mathrm{Fe}, \mathrm{Mn}, \mathrm{Cu}, \mathrm{Cr}$, and As. Awaleh et al. [14] examined characteristics of the thermal waters in the Obock coasts located in Djibouti (Africa), using a chemical geothermometer $\left(\mathrm{Na} / \mathrm{K}, \mathrm{Na}-\mathrm{K}-\mathrm{Ca}\right.$, and $\left.\mathrm{SiO}_{2}\right)$ to estimate the temperature in the geothermal reservoir at $197^{\circ} \mathrm{C}$. Based on the above, they proposed a model to examine the behavior of the fluid during its ascent, obtaining contributions from cold sea waters and waters without thermal contribution (freshwater). Also, Abdulkadir and Eritro [7] expressed the importance that hot springs, as touristic sites, have acquired in the Ethiopian province of the Rift Valley (Africa), since they play an important role in the local tourism industry and there is a need for detailed research and evaluation of possible uses for healing tourism and thermal, agricultural, and power generation.

Other studies have been carried out in places like the region where the present study was developed in Colombia. For example, Sturchio et al. [15] carried out chemical and isotope studies of hot springs, analyzing $\mathrm{S}$ deposits in the Puracé volcano and the Coconuco and San Juan sectors. Isotope measurements showed a correlation with magmatic sulfur origin in waters and gases. Both mentioned San Juan sector sources present absorption of magmatic gas in meteoric water after $\mathrm{CI}^{-}$loss and rock hydrolysis producing heated vapor. Fischer et al. [16] analyzed the chemical composition and isotopes of the Galeras volcano discharges in Colombia and determined that the hot spring sources from this area contained thermal sulphate acid, like the fumarole emissions of the volcano, suggesting that the shallow thermal waters directly absorb the gases emanating from the volcano itself. As these waters are rich in sulphated acid compounds, they acquire the capacity to dissolve rocks, producing a variation in the composition of the water, depending on the volcanic activity. INGEOMINAS (in Spanish: Instituto Colombiano de Geología y Minería) registers in its inventory reports of characterization of two thermal sources in the sector of San Juan, on August 15, 2012. Similarly, Garzón [17] reported studies from the following sources in the catalog of hot springs of southwestern Colombia: San Juan source with a temperature of $35^{\circ} \mathrm{C}$ and $\mathrm{pH}$ of 4.8 and with water classification of sulphated type and Guarqüelló source with temperature of $24^{\circ} \mathrm{C}, \mathrm{pH} 2.5$, and general classification sulphated acid water type. These records were dated August 29, 1997. Considering that the sources have been affected by various causes, it is necessary to make a current analysis, including new sources to characterize them.

\section{Geographic Location}

The geothermal system of interest for this study is located between the Pacific and the Atlantic oceans in the northern part of South America, in Colombia. The system contains many young or active volcanoes which provide a variety of geothermal systems [18, 19]. The study area comprising the Coconuco and San Juan sectors is located in the Andean region of Colombia, southeast of the city of Popayán, Department of Cauca, in the central mountain range as the star shows in Figure 1(a) [20].

Figure 1(b) shows the geographical location of the Coconuco and San Juan sectors, where the sample consisted of 8 sources (Coconuco) and 9 sources (San Juan) to be characterized. The codes, names, and geographical coordinates are listed in Table 1. The sources are described according to the reports developed by INGEOMINAS as follows: COPAL (grouping of outcrops in blue well mud), $\mathrm{COCH}$ (waterfall on the road), COAH (boiling water), COPS (saline pools), COCS (natural salines), COSJ (thermal outcrop-San Juan sector) (Figures 2(b) and 2(c)), COSJN (natural outcrop San Juan sector), COSN (San Nicolás natural fall), COCB (Bedón natural fall), CORP (Perico 1 dam) (Figure 2(d)), and COLA (Andulbio lagoon) [17].

Volcanic activity in Colombia is related to the interaction of the Nazca and the South American plates and presents geological-structural characteristics typical of an area with subduction processes along the continental margin [21]. The Puracé volcano is in the extreme northern end of the Coconucos volcanic chain, in the central mountain range of Colombia [22].

The Coconuco sector is located on the "Caldera de Chagartón" zone, southwest of the Puracé volcano, which is made up of remnants of ash pyroclastic flow, as well as volcanic breccias, mudflows, and morrhenic deposits. This caldera preserves remains of the volcanic cone and surroundings of the Puracé volcano [23]. Currently, the San Juan sector is located on the Puracé National Natural Park declared by UNESCO as a biosphere reserve in 1979. The lithological cross section is described in [24]. The purpose of the present work is the characterization and analysis of the physicalchemical properties of 8 sources in the Coconuco sector 

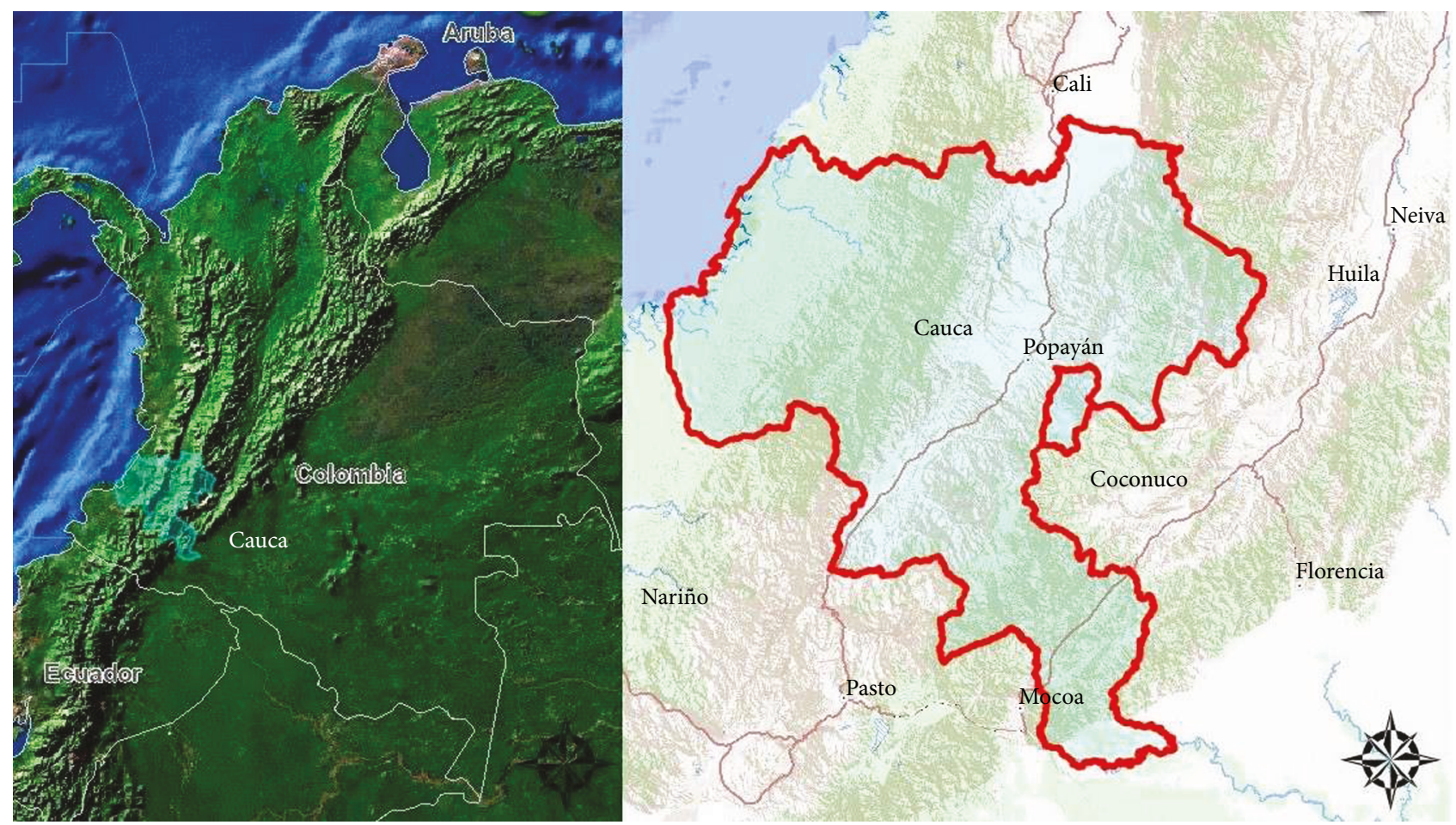

(a)

Coconuco and San Juan

$76^{\circ} 30^{\prime} 0^{\prime \prime} \mathrm{W} \quad 76^{\circ} 28^{\prime} 0^{\prime \prime} \mathrm{W} \quad 76^{\circ} 26^{\prime} 0^{\prime \prime} \mathrm{W} \quad 76^{\circ} 24^{\prime} 0^{\prime \prime} \mathrm{W} \quad 76^{\circ} 22^{\prime} 0^{\prime \prime} \mathrm{W} \quad 76^{\circ} 20^{\prime} 0^{\prime \prime} \mathrm{W} \quad 76^{\circ} 18^{\prime} 0^{\prime \prime} \mathrm{W}$

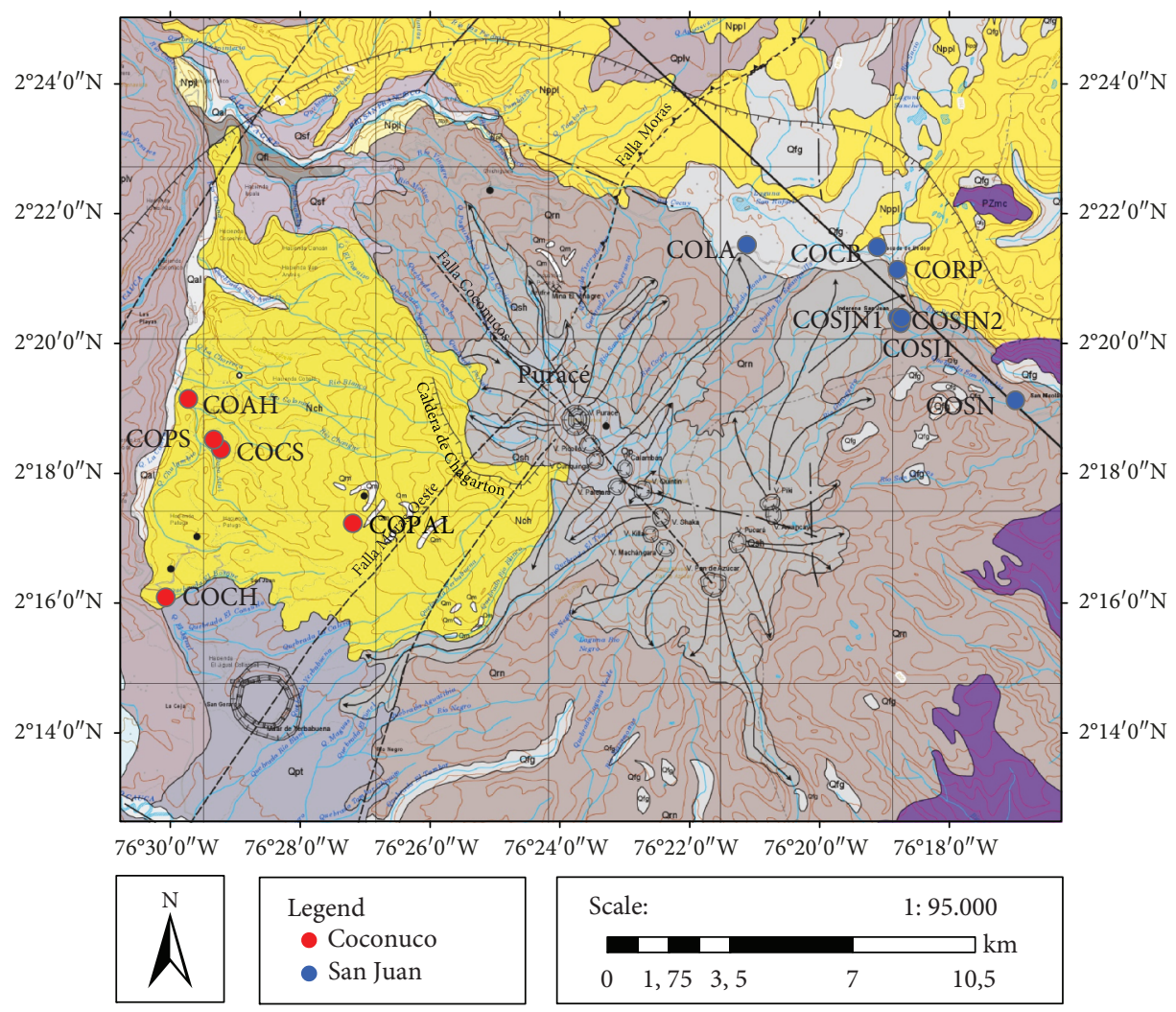

(b)

Figure 1: (a) Map of Colombia and Cauca region location and (b) location of monitoring sites of the San Juan sector. Official map of the Agustin Codazzi Geographic Institute. 
Table 1: Code, codification, coordinates, and references. Points of the Coconuco sector.

\begin{tabular}{|c|c|c|c|c|}
\hline \multirow{2}{*}{ Code } & \multirow{2}{*}{ Codification } & \multirow{2}{*}{ Source } & \multicolumn{2}{|c|}{ Coordinates } \\
\hline & & & $\mathrm{N}$ & $\mathrm{W}$ \\
\hline \multirow{2}{*}{ COPAL } & $\mathrm{CO} 3$ & Hot spring mud site 1 Pozo Azul & \multirow{2}{*}{$2^{\circ} 17.04^{\prime}$} & \multirow{2}{*}{$76^{\circ} 27.53^{\prime}$} \\
\hline & $\mathrm{CO} 4$ & Hot spring mud site 2 Pozo Azul & & \\
\hline $\mathrm{COCH}$ & CO6 & Waterfall in the road & $2^{\circ} 16.46^{\prime}$ & $76^{\circ} 30.40^{\prime}$ \\
\hline \multirow{2}{*}{$\mathrm{COAH}$} & $\mathrm{CO} 7$ & Water pool boiling water & \multirow{2}{*}{$2^{\circ} 19.48^{\prime}$} & \multirow{2}{*}{$76^{\circ} 29.22^{\prime}$} \\
\hline & $\mathrm{CO} 8$ & Soda water tank & & \\
\hline \multirow{2}{*}{ COPS } & CO9 & Sauna pool Salinas & \multirow{2}{*}{$2^{\circ} 18.16^{\prime}$} & \multirow{2}{*}{$76^{\circ} 29.12^{\prime}$} \\
\hline & CO11 & Outcrop hot spring Salinas & & \\
\hline COCS & $\mathrm{CO} 12$ & Natural waterfall Salinas & $2^{\circ} 18.11^{\prime}$ & $76^{\circ} 29.09^{\prime}$ \\
\hline \multirow{3}{*}{ COSJ1 } & SJ1 & Geyser outcrop 1 San Juan & $2^{\circ} 20^{\prime} 25^{\prime \prime}$ & $76^{\circ} 18^{\prime} 47^{\prime \prime}$ \\
\hline & SJ2 & Geyser outcrop 2 San Juan & $2^{\circ} 20^{\prime} 25^{\prime \prime}$ & $76^{\circ} 21^{\prime} 02^{\prime \prime}$ \\
\hline & SJ3 & Natural outcrop San Juan & $2^{\circ} 20^{\prime} 26^{\prime \prime}$ & $76^{\circ} 18^{\prime} 49^{\prime \prime}$ \\
\hline COSJN1 & SJ4 & Surface water source, right side entrance San Juan & $2^{\circ} 20^{\prime} 28^{\prime \prime}$ & $76^{\circ} 18^{\prime} 48^{\prime \prime}$ \\
\hline COSJN2 & SJ5 & Surface water source, in front of the stand & $2^{\circ} 20^{\prime} 23^{\prime \prime}$ & $76^{\circ} 18^{\prime} 48^{\prime \prime}$ \\
\hline COSN & SJ7 & San Nicolás exit & $2^{\circ} 19^{\prime} 10^{\prime \prime}$ & $76^{\circ} 16^{\prime} 56^{\prime \prime}$ \\
\hline COCB & SJ9 & Bedón fall & $2^{\circ} 21^{\prime} 28^{\prime \prime}$ & $76^{\circ} 19^{\prime} 01^{\prime \prime}$ \\
\hline CORP & SJ10 & Perico dam & $2^{\circ} 21^{\prime} 05^{\prime \prime}$ & $76^{\circ} 18^{\prime} 47^{\prime \prime}$ \\
\hline COLA & SJ11 & Andulbio lagoon & $2^{\circ} 21^{\prime} 32^{\prime \prime}$ & $76^{\circ} 21^{\prime} 02^{\prime \prime}$ \\
\hline
\end{tabular}

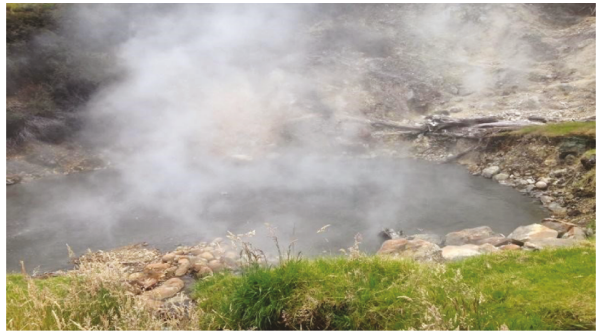

(a)

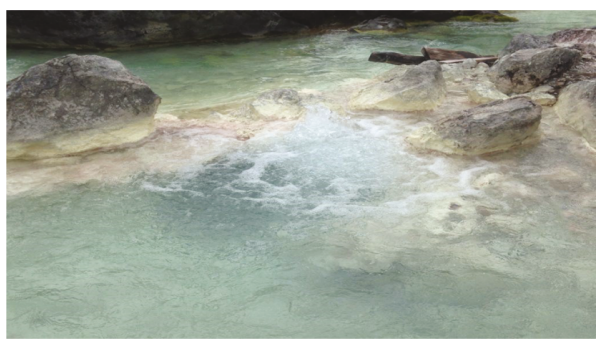

(c)

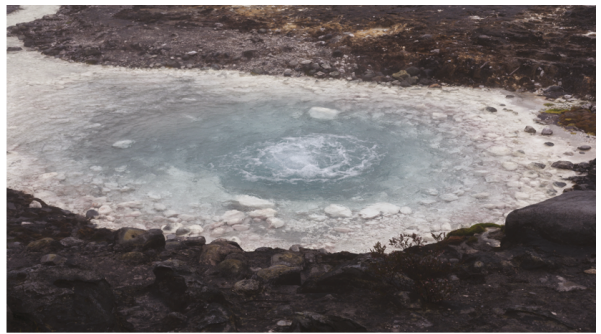

(b)

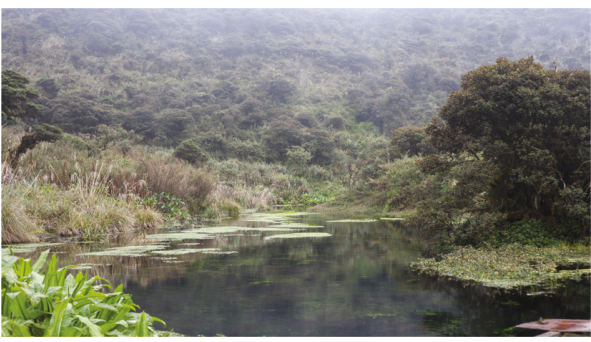

(d)

Figure 2: (a) Source Pozo Azul, (b) geyser outcrop 1, (c) geyser outcrop 3, and (d) Perico dam.

and 9 sources in the San Juan sector (Cauca, Colombia, South America). In addition, by means of XRD and XRF, representative rocks of several sectors were analyzed in order to determine the mineralogic composition and relate this with thermal fluids.

\section{Sampling and Analysis Methodology}

3.1. Sampling. Eight representative samples from the Coconuco sector and nine samples from the San Juan sector were tested for physicochemical analyses. The type of 
sampling performed was simple or timely. The sampling was carried out in 10-liter graduated containers. The vessel was purged two or three times, and it was then placed in the flow, measuring it with a timer. In this way, the parameter $Q=V / t$ was obtained. The flow $Q$ was given in $L / s$, where $V$ and $t$ represented the volume and time, respectively. During the sampling, $\mathrm{HNO}_{3}$ was added reaching $\mathrm{pH}<2$ for hardness and metal analyses; $\mathrm{pH}$, temperature, and conductivity parameters were measured for all samples. Titanium and ORP analyses were not carried out in this study.

The seven representative solid samples of the sector were taken in the sources SJ1-A, SJ1-B, SJ1-C, SJ6-C, CO2-A, CO3-A, CO11-A, and CO13-A for the XRD and XRF analyses.

\subsection{Analysis Methodology}

3.2.1. Characterization of the Thermal Sources. Physicochemical characterization of the sources was carried out in the Water Laboratory at Universidad Nacional de ColombiaManizales, based on Standard Methods 22nd edition [25]. The laboratory is accredited by IDEAM (Instituto de Hidrología, Meteorología y Estudios Ambientales, for its acronym in Spanish) through the ISO standard 17025. Some of the methods of analysis are described as follows: total hardness was determined by means of the 2340-C EDTA; nitrates were determined by means of the $4500-\mathrm{NO}_{3}-\mathrm{B}$ method; $\left(\mathrm{SO}_{4}\right)^{2-}$ ions were determined by means of the 4500 $\left(\mathrm{SO}_{4}\right)^{2-}-\mathrm{E}$ method; and the $4500-\mathrm{Cl}^{-} \mathrm{B}$ method was used to determine $\mathrm{Cl}^{-}$ions. Atomic absorption by flame was applied for metal detection using the iCE 3000 Thermo Scientific equipment, and the limits of detection are shown in Table 2. Turbidity was determined by means of the 2130-B method. A Metrohm Swiss-made device was used for the pH-L measurements, and a Metrohm Swiss-quality titration equipment was used for the multiprobe analysis. The methods of analysis are detailed in [24].

3.2.2. Mineralogical Characterization. The mineralogical characterization was carried out in the $\mathrm{GMAS}^{+}$Laboratory Bogotá, Colombia. For the XRD and XRF analysis, the samples were pulverized and sieved with $63 \mu \mathrm{m}$ nets and an approximate weight of $2.0 \mathrm{~g}$. The mineralogical composition and structural parameters of the rocks were evaluated by $\mathrm{XRD}$ with an X-ray diffractometer (Bruker D8 Advanceseries I) that was operated at $20 \mathrm{kV}$ and $30 \mathrm{~mA}$, with an $\mathrm{X}$-ray source emitting Co K $(1.7890 \mathrm{~A})$ radiation. The measuring range was from 5 to 70 with $0.3 \mathrm{~s}$ /step scan speed and 0.015 step size, and a nickel filter was used. The analysis was carried out using the EVA [26] and TOPAS software [27]. The details of the analysis are described in [24].

\section{Results}

4.1. Physical-Chemical Analyses. The physical-chemical analyses of the 17 sources of the Coconuco and San Juan sectors are presented in Tables 3(a) and 3(b). In the chemical results, the absence or low concentration of metals such as $\mathrm{Al}, \mathrm{Fe}, \mathrm{Cr}$, $\mathrm{Mn}$, and $\mathrm{Zn}$ was observed. Likewise, nitrates, nitrites, fluorides, and carbonates and high concentrations of sulphate
TABLe 2: Atomic absorption by flame.

\begin{tabular}{lc}
\hline Metal & Detection limit $(\mathrm{ppm})$ \\
\hline $\mathrm{Fe}$ & 0.0043 \\
$\mathrm{Al}$ & 0.0280 \\
$\mathrm{Zn}$ & 0.0037 \\
$\mathrm{Na}$ & 0.0037 \\
$\mathrm{~K}$ & 0.0009 \\
$\mathrm{Ca}$ & 0.0037 \\
$\mathrm{Mg}$ & 0.0022 \\
$\mathrm{Mn}$ & 0.0016 \\
\hline
\end{tabular}

ions, total hardness, and calcium were noticed. Moreover, it was observed that, except for sources CO6, CO8, SJ11, and SJ7, the other sources had high values in the concentration of $\left(\mathrm{SO}_{4}\right)^{2-}$ ions. In the CO8, SJ1, and SJ3 sources, the calcium concentration exceeded $200 \mathrm{mg} / \mathrm{L}$. In the physical parameters, the temperatures of the Coconuco sector registered values up to $81.0^{\circ} \mathrm{C}$ and in San Juan up to $34^{\circ} \mathrm{C}$ and $\mathrm{pH}$ between 3.4 and 7.88. In this case, a variation in the $\mathrm{pH}$ was observed once measured in the laboratory (Table 3(b)). A decrease in the pH-L was noticed. In general, changes in the $\mathrm{pH}$ were generated with the variations of temperature when there was an increase in temperature generating vibrations in the molecules, thus producing a decrease in the formation of hydrogen bonds and a decrease in the $\mathrm{pH}$.

The charge imbalance was carried out using the PHREEQC software. In this case, values above $10 \%$ were observed which are attributed to different events such as the oxidation of compounds and elements, degasification of $\mathrm{CO}_{2}$, and decrease in temperature, which generates an increase in $\mathrm{H}^{+}$ions that were considered in the load balance. This process was mentioned in previous works [24]. On the other hand, errors were greater when the total sum of ions was less than $5 \mathrm{mEq} / \mathrm{L}$ [28]. The other sources were discarded from this study.

Once the results of the laboratory analyses were obtained, the classification by major ions was performed using Piper (Coconuco (Figure 3(a)) and San Juan (Figure 3(b))) and Stiff diagrams.

According to the analysis of Piper diagrams, the geochemical classification from major ions was made as follows.

Table 4 shows the chemical classification of the 17 sources according to the anions and cations. In the classification, according to the cations, 9 sources were of the calcium type. From these sources, $4\left(^{*}\right)$ of them, although containing calcic-type character in the Piper diagrams, did not exceed $1 \mathrm{mEq} / \mathrm{L}$ in the Stiff diagrams (Figures 4(a), 4(c), and 4(d)). Four sources were of the sodium type: one source was slightly calcic and the three other sources were partially balanced waters. In the classification according to anions, most sources were sulphated. From this classification, the San Nicolás exit $\left({ }^{* *}\right)$ recorded sulphated type in the ternary diagram, but in Stiff's diagram (Figure 4(b)), it did not exceed $1 \mathrm{mEq} / \mathrm{L}$ and only one source was partially balanced waters and slightly bicarbonated. 
TABle 3: Major element concentrations of the geothermal waters from the Coconuco and San Juan sectors, Cauca, Colombia.

(a)

\begin{tabular}{|c|c|c|c|c|c|c|c|c|c|c|c|c|c|c|}
\hline Source & $\mathrm{SO}_{4}^{2-}$ & $\mathrm{CI}^{-}$ & $\mathrm{Na}^{+}$ & $\mathrm{K}^{+}$ & $\mathrm{Ca}^{2+}$ & $\mathrm{Mg}^{2+}$ & $\mathrm{Fe}$ & $\mathrm{Mn}$ & $\mathrm{Al}^{3+}$ & $\mathrm{HCO}_{3}$ & $\mathrm{CO}_{3}$ & $\mathrm{CaCo}_{3}$ & CI & TI \\
\hline $\mathrm{CO} 3$ & 103.6 & 2.8 & 10.1 & 5.9 & 21.1 & 5.9 & 1.9 & $<\mathrm{IDL}$ & 1.7 & 0.0 & 0.0 & 79.2 & 15.6 & 4.4 \\
\hline $\mathrm{CO} 4$ & 138.8 & 3.4 & 9.4 & 3.5 & 19.1 & 5.1 & $<\mathrm{IDL}$ & $<\mathrm{IDL}$ & $<\mathrm{IDL}$ & 67.7 & 0.0 & 55.4 & 42.41 & 6.0 \\
\hline $\mathrm{CO} 6$ & 13.1 & 0.5 & 4.7 & 2.1 & 14.9 & 1.8 & 1.5 & 0.02 & $<\mathrm{IDL}$ & 26.1 & 0.0 & 21.8 & 19.93 & 1.9 \\
\hline $\mathrm{CO} 7$ & 1067.5 & 1536.5 & 1572.1 & 221.4 & 207.8 & 38.0 & $<\mathrm{IDL}$ & 3.5 & $<\mathrm{IDL}$ & 728.1 & 0.0 & 4.9 & 4.81 & 165.0 \\
\hline $\mathrm{CO} 8$ & 3.9 & 3.0 & 5.6 & 3.0 & 8.1 & 2.8 & 0.9 & 0.6 & $<\mathrm{IDL}$ & 42.5 & 0.0 & 90.0 & 0.30 & 1.8 \\
\hline CO9 & 535.2 & 367.4 & 352.7 & 70.1 & 63.1 & 5.4 & $<\mathrm{IDL}$ & 0.1 & $<\mathrm{IDL}$ & 0.0 & 0.0 & 66.3 & 0.98 & 42.2 \\
\hline CO11 & 570.0 & 437.1 & 416.1 & 18.3 & 53.7 & 6.0 & 0.6 & 0.2 & $<\mathrm{IDL}$ & 0.0 & 0.0 & 79.7 & 4.85 & 45.9 \\
\hline $\mathrm{CO} 12$ & 91.9 & 7.0 & 8.1 & 3.1 & 17.3 & 3.8 & $<\mathrm{IDL}$ & $<\mathrm{IDL}$ & $<\mathrm{IDL}$ & 43.8 & 0.0 & 55.4 & 31.56 & 4.4 \\
\hline SJ1 & 310.8 & 30.7 & 47.2 & 10.3 & 206 & 47.5 & $<\mathrm{IDL}$ & 1.7 & $<\mathrm{IDL}$ & 28.1 & 0.0 & 990.0 & 43.1 & 24.4 \\
\hline SJ2 & 975.9 & 26.4 & 49.0 & 9.7 & 222.2 & 50.3 & $<\mathrm{IDL}$ & 1.6 & $<\mathrm{IDL}$ & 20.3 & 0.0 & 1030.0 & 13.91 & 39.1 \\
\hline SJ3 & 907.4 & 47.2 & 54.7 & 11.0 & 234.1 & 52.2 & $<\mathrm{IDL}$ & 1.6 & $<\mathrm{IDL}$ & 26.6 & 0.0 & 961.3 & 7.05 & 39.4 \\
\hline SJ4 & 173.8 & 2.0 & 2.6 & 1.7 & 17.1 & 3.2 & $<\mathrm{IDL}$ & $<\mathrm{IDL}$ & $<\mathrm{IDL}$ & 5.0 & 0.0 & 79.2 & 52.94 & 5.0 \\
\hline SJ5 & 296.6 & 6.0 & 11.1 & 4.6 & 66.8 & 14.7 & $<\mathrm{IDL}$ & 0.4 & $<\mathrm{IDL}$ & 4.3 & 0.0 & 250.0 & 12.72 & 11.6 \\
\hline SJ7 & 47.6 & 0.9 & 0.6 & 0.6 & 1.2 & 0.5 & $<\mathrm{IDL}$ & $<\mathrm{IDL}$ & $<\mathrm{IDL}$ & 9.6 & 0.0 & 80.0 & 79.61 & 1.3 \\
\hline SJ9 & 177.8 & 3.6 & 3.6 & 2.8 & 14.3 & 4.0 & $<\mathrm{IDL}$ & $<\mathrm{IDL}$ & $<\mathrm{IDL}$ & 23.7 & 0.0 & 72.3 & 57.44 & 5.5 \\
\hline SJ10 & 95.5 & 1.0 & 3.5 & 1.7 & 15.7 & 2.3 & $<\mathrm{IDL}$ & $<\mathrm{IDL}$ & $<\mathrm{IDL}$ & 14.6 & 0.0 & 49.5 & 34.5 & 3.4 \\
\hline SJ11 & 2.9 & 3.0 & 0.8 & 0.3 & 1.1 & 0.3 & $<\mathrm{IDL}$ & $<\mathrm{IDL}$ & $<\mathrm{IDL}$ & 6.3 & 0.0 & 16.0 & 37.9 & 0.4 \\
\hline
\end{tabular}

(b)

\begin{tabular}{|c|c|c|c|c|c|c|c|c|c|c|c|c|c|c|}
\hline Source & $\mathrm{F}^{-}$ & $t^{\circ} \mathrm{C}$ & $\mathrm{pH}-\mathrm{S}$ & $\mathrm{pH}-\mathrm{L}$ & $\mathrm{F}$ & $\mathrm{C}$ & SST & $\mathrm{NO}_{3}$ & $\mathrm{NO}_{2}$ & $\mathrm{Cr}$ & $\mathrm{Zn}$ & $\mathrm{Si}$ & $\mathrm{DO}$ & $\mathrm{Na} / \mathrm{K}$ \\
\hline $\mathrm{CO} 3$ & 0.02 & 81.0 & 3.4 & 3.6 & 0.003 & 303.0 & 5.5 & 0.1 & 1.4 & $<\mathrm{IDL}$ & $<\mathrm{IDL}$ & 28.3 & 0.0 & 1.17 \\
\hline $\mathrm{CO} 4$ & 0.02 & 25.2 & 6.8 & 6.0 & 1.8 & 135.8 & 24.0 & 0.2 & ND & $<\mathrm{IDL}$ & $<\mathrm{IDL}$ & 28.4 & 0.0 & 2.69 \\
\hline CO6 & 0.01 & 13.5 & 7.7 & 5.5 & 54.8 & 51.4 & 39.0 & 0.1 & 3.0 & $<\mathrm{IDL}$ & $<\mathrm{IDL}$ & 5.6 & 7.2 & 2.24 \\
\hline $\mathrm{CO} 7$ & 0.1 & 70.0 & 3.9 & 3.9 & 3.1 & 8250 & 4.0 & 2.9 & 6.3 & $<\mathrm{IDL}$ & $<\mathrm{IDL}$ & 46.4 & 0.0 & 7.10 \\
\hline $\mathrm{CO} 8$ & 0.01 & 19.8 & 5.7 & 4.9 & 0.2 & 109.7 & 2.0 & 0.2 & 1.6 & $<\mathrm{IDL}$ & $<\mathrm{IDL}$ & 17.5 & 0.0 & 1.87 \\
\hline CO9 & 0.06 & 72.0 & 3.7 & 3.4 & -- & 2030 & 4.0 & 0.05 & ND & $<\mathrm{IDL}$ & $<\mathrm{IDL}$ & 101.4 & 0.0 & 5.03 \\
\hline CO11 & 0.07 & 15.9 & 3.7 & 3.2 & 0.1 & 2390 & 7.5 & 0.1 & ND & $<\mathrm{IDL}$ & $<\mathrm{IDL}$ & 113.1 & 0.0 & 22.74 \\
\hline $\mathrm{CO} 12$ & 0.01 & 15.9 & 7.6 & 5.6 & 20.6 & 146.0 & 8.5 & 0.1 & 0.4 & $<\mathrm{IDL}$ & $<\mathrm{IDL}$ & 24.1 & 7.0 & 2.61 \\
\hline SJ1 & 0.0 & 33.7 & 5.14 & 5.1 & 20.6 & 1397 & 6.5 & 0.3 & ND & $<\mathrm{IDL}$ & $<\mathrm{IDL}$ & 44.6 & 0.0 & 4.58 \\
\hline SJ2 & 0.0 & 32.9 & 5.09 & 5.0 & ND & 1458 & 1.0 & 0.0 & ND & $<\mathrm{IDL}$ & $<\mathrm{IDL}$ & 45.4 & 0.0 & 5.05 \\
\hline SJ3 & 0.0 & 31.2 & 5.15 & 5.2 & ND & 1413 & 2.5 & 0.0 & 1.3 & $<$ IDL & $<\mathrm{IDL}$ & 44.1 & 0.0 & 4.97 \\
\hline SJ4 & 0.0 & 10.1 & 7.63 & 5.7 & ND & 135.4 & 3.0 & 0.1 & ND & $<\mathrm{IDL}$ & $<\mathrm{IDL}$ & 6.0 & 7.5 & 1.53 \\
\hline SJ5 & 0.0 & 9.6 & 7.88 & 5.0 & 589.8 & 460.0 & 18.5 & 0.0 & 0.4 & $<\mathrm{IDL}$ & $<\mathrm{IDL}$ & 14.4 & 7.2 & 2.41 \\
\hline SJ7 & 0.0 & 11.1 & 7.55 & 5.4 & 146.6 & 16.5 & 10.0 & ND & 1.7 & $<\mathrm{IDL}$ & $<\mathrm{IDL}$ & $<\mathrm{IDL}$ & 7.0 & 1.00 \\
\hline SJ9 & 0.0 & 12.5 & 7.66 & 5.8 & ND & 149.0 & 4.0 & 0.0 & ND & $<\mathrm{IDL}$ & $<\mathrm{IDL}$ & 7.1 & 7.0 & 1.29 \\
\hline SJ10 & 0.0 & 8.0 & 7.49 & 6.1 & 74.4 & 87.4 & 19.0 & 0.1 & 0.4 & $<\mathrm{IDL}$ & $<\mathrm{IDL}$ & 5.5 & 0.0 & 2.06 \\
\hline SJ11 & 0.0 & 13.0 & 7.78 & 6.5 & ND & 8.7 & 13.0 & 0.1 & 0.6 & $<\mathrm{IDL}$ & $<\mathrm{IDL}$ & $<\mathrm{IDL}$ & 7.1 & 2.67 \\
\hline
\end{tabular}

Units are in ppm. $<$ DL: less than detection limit; ND: not detectable. (a) CI: charge imbalance; mEq/L; total ions. (b) pH-L: laboratory; pH-S: on site; SST: suspended solid totals; C: conductivity $(\mu \mathrm{S}=\mathrm{cm})$; F: flow on $\mathrm{L}=\mathrm{s}$; DO: dissolved oxygen.

4.2. $\mathrm{Cl}^{-},\left(\mathrm{SO}_{4}\right)^{2-}$, and $\left(\mathrm{HCO}_{3}\right)^{-}$Giggenbach Diagram. Figures 5(a) and 5(b) show the classification according to the ternary diagram of $\mathrm{Cl}^{-},\left(\mathrm{SO}_{4}\right)^{2-}$, and $\left(\mathrm{HCO}_{3}\right)^{-}$described by Giggenbach [29]. In this diagram, the Coconuco sector presents sources of different chemical composition (less mature water). On the contrary, the San Juan sector contains most of its sources with similar chemical compositions, which are located at the end of the ion $\left(\mathrm{SO}_{4}\right)^{2-}$ between steam-heated waters and volcanic waters and only the SJ11 source is on the peripheral waters.

The CO6, CO8, and SJ11 sources are peripheral and shallow waters; however, the $\mathrm{HCO}_{3}$ content is not relatively high. The sources present on steam-heated waters (CO4 and CO12) are characterized by moderate contents of 


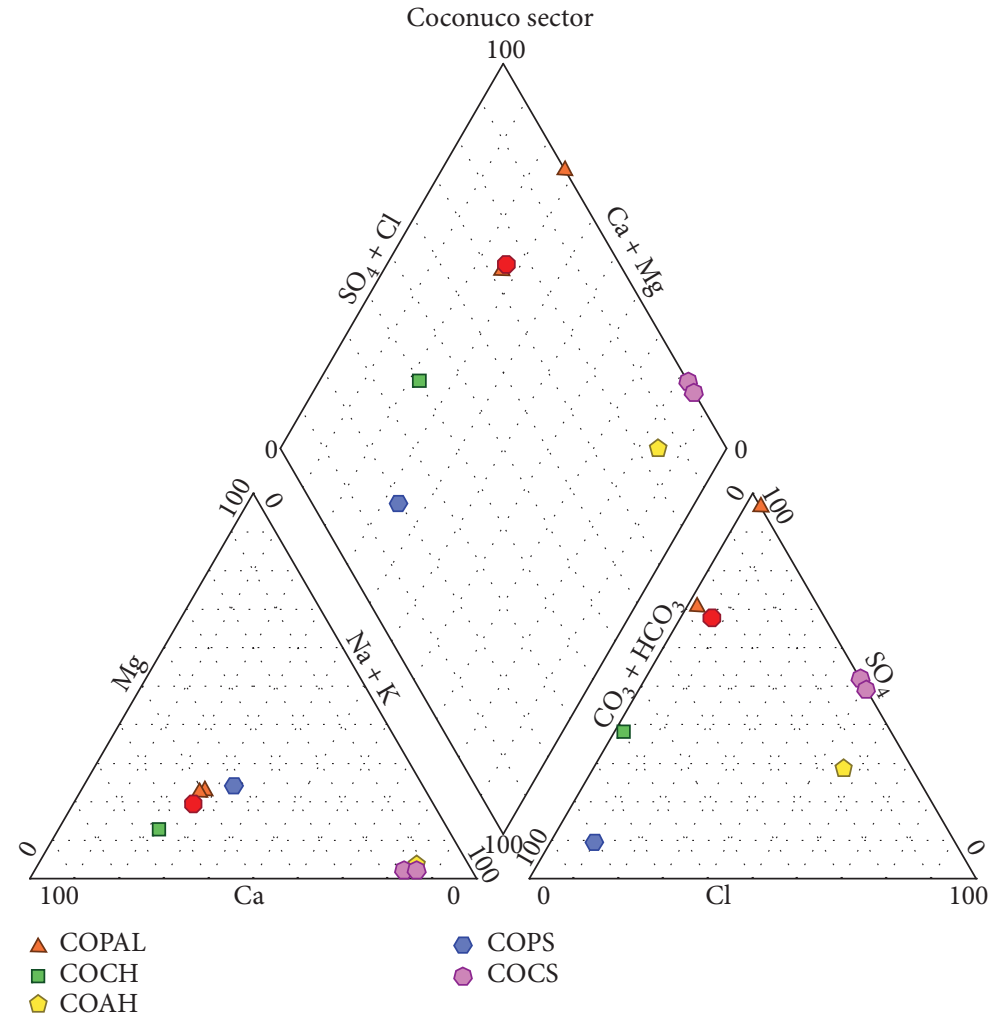

(a)

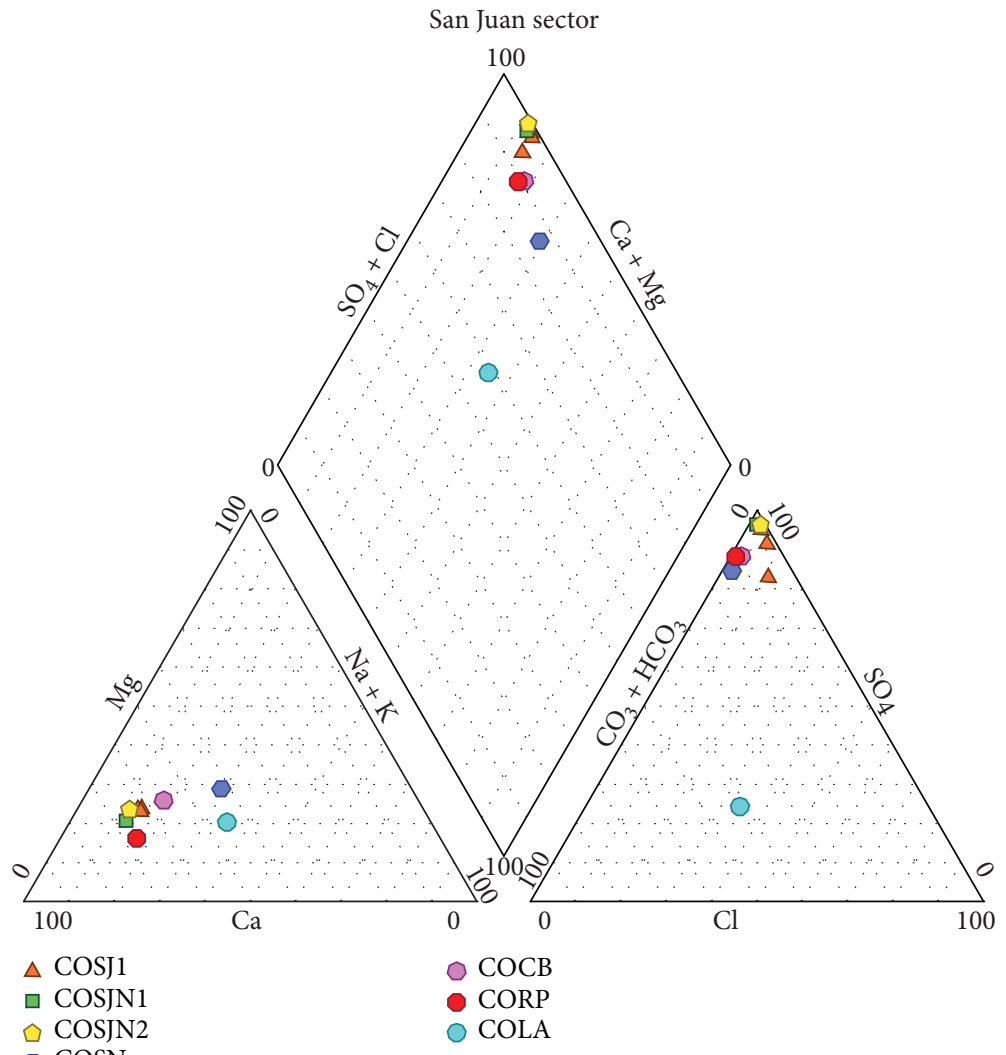

(b)

FIgURE 3: Piper diagram showing the hydro chemical compositions: (a) Coconuco sector and (b) San Juan sector. 
TABLE 4: Chemical classification of waters of the San Juan sector, according to cations, anions, and water type.

\begin{tabular}{lccc}
\hline Source & Cations & Anions & Water type \\
\hline CO3 & Partially equilibrated & Sulphated type & Sulphated calcium \\
CO4 & Calcium type & Sulphated type & Sulphated calcium \\
CO6 & Calcium type* & Slightly bicarbonated type & Calcium bicarbonated slightly \\
CO7 & Sodium type & Chlorinated type & Culphated and chlorinated-calcium and potassium \\
CO8 & Partially equilibrated & Slightly bicarbonated type & Carbonated slightly \\
CO9 & Sodium type & Slightly sulphated type & Sodium chloride and potassium-sulphated calcium \\
CO11 & Sodium type & Slightly sulphated type & Sodium chloride and potassium-sulphated calcium \\
CO12 & Sodium type & Sulphated type & Sulphated and calcium bicarbonated slightly \\
SJ1 & Calcium type & Sulphated type & Sulphated calcium and magnesium \\
SJ2 & Calcium type & Sulphated type & Sulphated calcium and magnesium \\
SJ3 & Calcium type & Sulphated type & Sulphated calcium and magnesium \\
SJ4 & Calcium type* & Sulphated type & Sulphated \\
S55 & Calcium type & Sulphated type & Sulphated calcium \\
SJ7 & Partially equilibrated & Sulphated type* & Sulphated \\
S59 & Calcium type* & Sulphated type & Sulphated \\
SJ10 & Calcium type* & Sulphated type & Sulphated \\
SJ11 & Partially equilibrated & Partially equilibrated & Partially equilibrated
\end{tabular}

$\left(\mathrm{SO}_{4}\right)^{2-}$ and magmatic or volcanic waters that generally have $\mathrm{HCO}_{3}$ concentrations close to zero and high contents of $\left(\mathrm{SO}_{4}\right)^{2-}$ and $\mathrm{Cl}^{-}$ions [30].

Source SJ11 (Andulbio lagoon) can be classified as peripheral waters. These neutral fluids (see Table 4) possess several features like their hydrothermal origin (generally formed by the absorption of $\mathrm{CO}_{2}$ ), the isolation from geothermal fluids [31], their far from equilibrium state (despite that they have interacted with rocks), their low contents of $\mathrm{HCO}^{-}$, and their neutral $\mathrm{pH}$ (see Figure 4(e)). This indicates that the sources can be fed by lateral flows in lavas of the breastplate of dacite rocks of the cone-shaped pyroclastic flow [15].

4.3. $\mathrm{Na}^{+}-\mathrm{K}^{+}-\mathrm{Mg}^{2+}$ Diagram. Also called Giggenbach diagram, the $\mathrm{Na}^{+}-\mathrm{K}^{+}-\mathrm{Mg}^{2+}$ diagram allows establishing a physical-chemical equilibrium between the rock and the fluid and thus studying the maturity of the waters by means of the main cations $\mathrm{Na}^{+}-\mathrm{K}^{+}-\mathrm{Mg}^{2+}[32]$.

Figures 6(a) and 6(b) show how most of the sources are close to $\mathrm{Mg}^{2+}$, which indicates that the upwellings of the Coconuco and San Juan sectors are immature waters and they have not reached the chemical equilibrium. The geothermometer is useful for obtaining information about the superficial balance and thermal water temperatures $[29,33]$. Likewise, Giggenbach mentions that this type of water (acid water, see Figure 3 and Table 4) is not suitable to evaluate the temperature by means of the $\mathrm{Na} / \mathrm{K}$ relation [29]. This indicates that these waters do not interact for long enough with the rocks. This is the reason why Sturchio et al. [15], in studies developed in two San Juan sources, only reported the isotope geothermometer of $\mathrm{O}$ $\left(98^{\circ} \mathrm{C}\right)$ and $\mathrm{S}\left(255^{\circ} \mathrm{C}\right)$.

However, the CO7, CO9, and CO11 sources of the Coconuco sector moved a little towards partial equilibrium.
The reservoir temperature was determined for these sources. The temperatures of the geothermal deposits of the Coconuco sector were established for the CO7, CO9, and CO11 sources using the chemical geothermometer of $\mathrm{K}^{+} / \mathrm{Mg}^{2+}$ through equation (1), established by Giggenbach [29].

$$
t=\frac{4410}{13,95-\log \left(\mathrm{K}^{2} / \mathrm{Mg}\right)}-273,15
$$

The $\mathrm{K}^{+} / \mathrm{Mg}^{2+}$ geothermometer allows observing the balance between the mineral and the fluid at low temperatures thanks to the temperature variations, thus reinforcing the concept that the surface geothermal fluids are mixed with cold water in the deposits [34-36]. In the CO7 source (boiling water pool), it presented a temperature of $133.7^{\circ} \mathrm{C}$, showing a decrease of $\sim 2,3^{\circ} \mathrm{C}$ compared to what was reported by Sturchio et al. [15] in this source. The sources CO9 and CO11 present temperatures of $128.1^{\circ} \mathrm{C}$ and $88.2^{\circ} \mathrm{C}$, respectively.

4.4. Binary Relations. The $\mathrm{Na} / \mathrm{K}$ ratios mentioned in Table 3(b) in the sources CO7, CO9, CO11, SJ1, SJ2, and SJ3, which present values above 4 and up to 20 , indicate a weak water-rock interaction with hydrothermal systems during the ascent to the surface, being consistent with low concentrations of $\mathrm{HCO}_{3}^{-}$(except the source CO7) [37]. The $\mathrm{Ca}^{2+} / \mathrm{Mg}^{2+}$ ratio presents low values, which is an evidence of the lack of direct migration of fluids. Likewise, the high contents of $\mathrm{Ca}^{2+}$ and $\mathrm{Mg}^{2+}$ cations stand out compared to the low concentration of $\mathrm{Na}^{+}$and $\mathrm{K}^{+}$species. This suggests that the sources were possibly mixed with cold waters rich in $\mathrm{Ca}^{2+}$ and $\mathrm{Mg}^{2+}[38]$.

On the other hand, the ion relations described by Hou et al. [37] were considered as it is observed in 


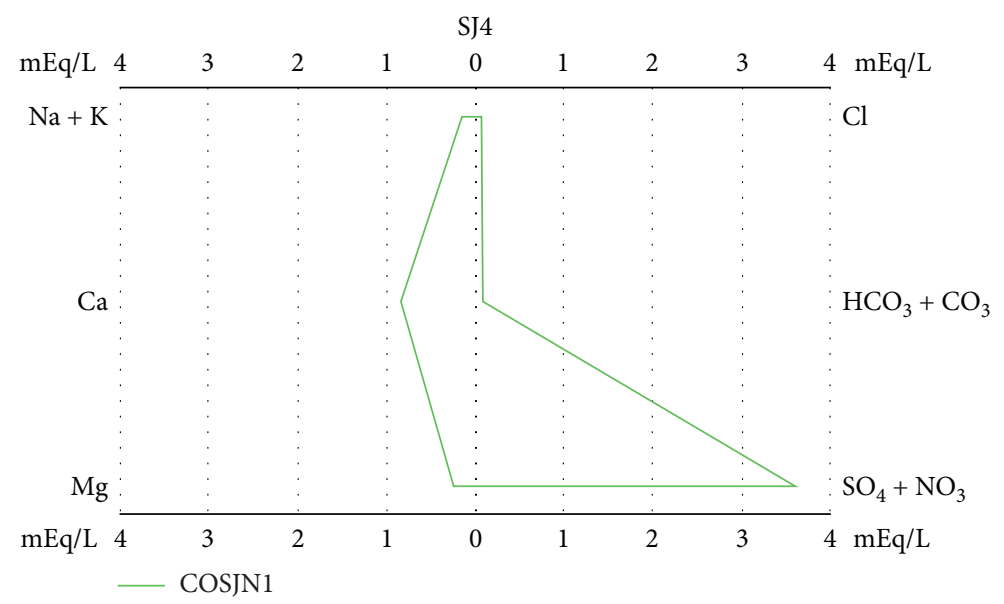

(a)

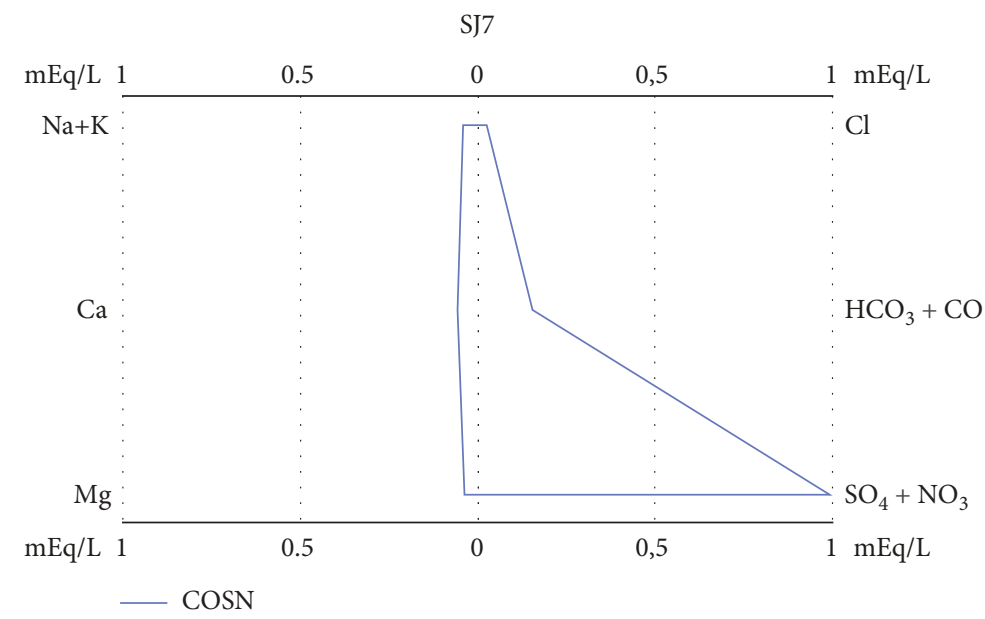

(b)

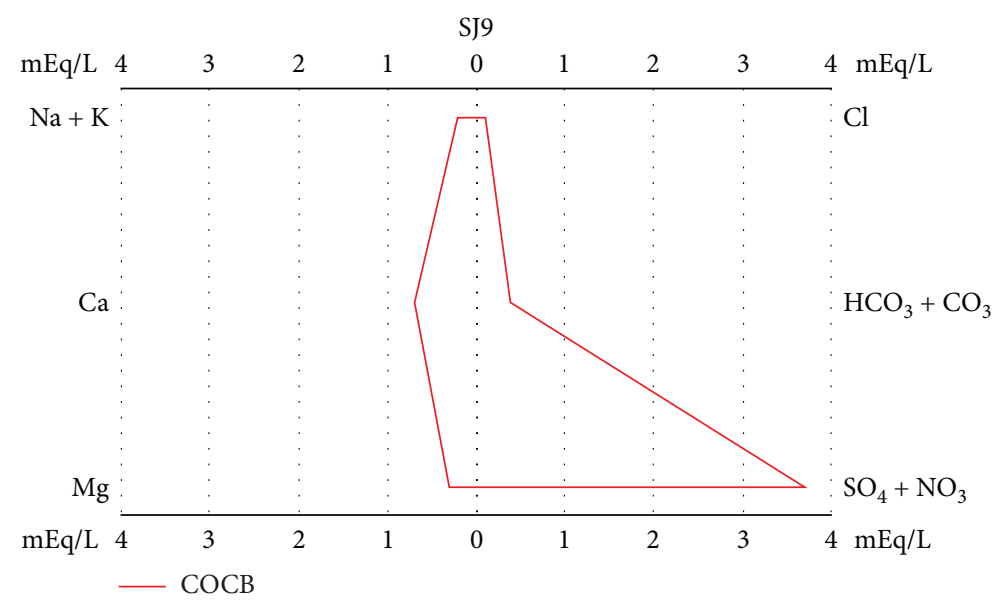

(c)

Figure 4: Continued. 


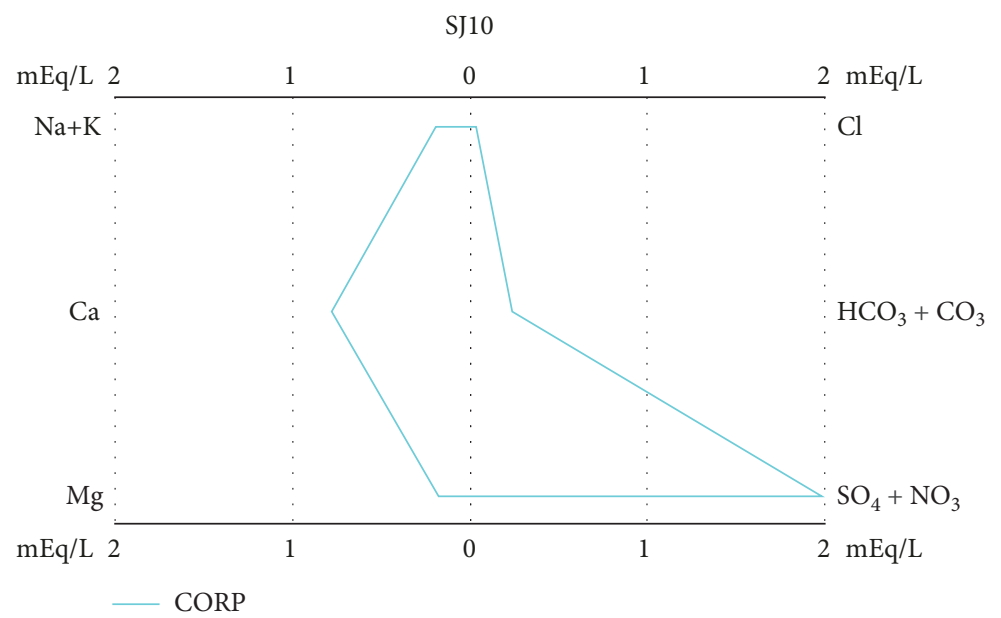

(d)

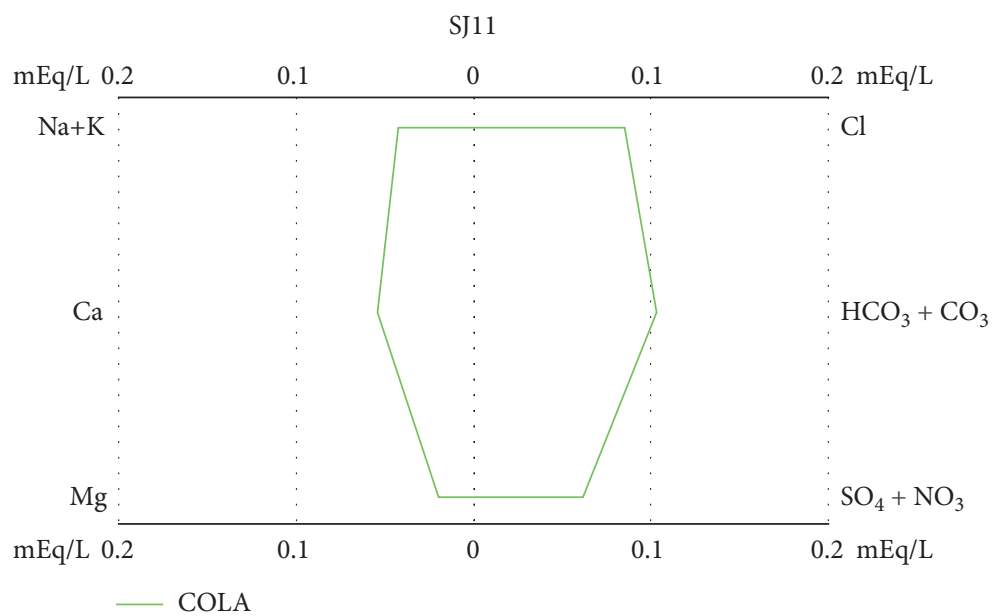

(e)

FIgURE 4: Representative Stiff diagrams of the sources of the San Juan sector.

Figure 7. Here, $2+$ and $2-$ vs. $1+$ and $1-$ ion relations presented a linear behavior with a determination coefficient of $R^{2}=0.929$ in the Coconuco sector and $R^{2}=0.620$ in the San Juan sector. Note that the SJ1 source does not follow the other sources' linear tendency. Sources of the Coconuco sector are located in the upper part of the line with equation $y=-0.654 x-1.473$ (see Figure $7(\mathrm{a})$ ) indicating a cation exchange between $\mathrm{Ca}^{2+}, \mathrm{Mg}^{2+}$, and $\mathrm{Na}^{+}$, which are dominant in the process of hydrogeochemical evolution and the possible dilution of albite rocks at the interior of the deposit. However, in the San Juan sector, the linearity is lower, which would indicate that the change in cations is not as dominant as in the Coconuco sector. These processes are caused when a cation in an aqueous medium possesses high adsorption strength, generating the travel of cations adhered to clay. Considering that the sources are located in the lower part of the line shown in Figure 7 , this $\left(\mathrm{Na}^{+}+\mathrm{K}^{+}\right)-\mathrm{CI}^{-}$and $\left(\mathrm{Ca}^{2+}+\mathrm{Mg}^{2+}\right)-\left(\left(\mathrm{HCO}_{3}\right)^{-}+\left(\mathrm{CO}_{3}\right)^{2-}+\left(\mathrm{SO}_{4}\right)^{2-}\right)$ relationship is attributed to the hydrogeochemical exchange of ion processes.

In the relationships of $\mathrm{Cl}$ vs. $\mathrm{Na}, \mathrm{K}, \mathrm{Ca}$, and $\mathrm{Mg}$, a positive relation is observed in all the samples (Figure 8) as well as high values of correlation, which are the product of geothermal fluids of $\mathrm{Na}-\mathrm{Cl}$. Nevertheless, some $\mathrm{Cl}$ ions are conserved in the environment and their concentration is not usually affected as it happens with $\mathrm{Na}$ by interactions [39], and, additionally, it indicates that the predominant salts are $\mathrm{Na}-\mathrm{Cl}$. In the case of $\mathrm{Cl}^{-}$and $\mathrm{Ca}^{2+}$, it indicates the prevalence of chloride-calcic-type fluids; likewise, the $\mathrm{Ca}^{2+}$ and $\mathrm{Mg}^{2+}$ cations are the main ones of hardness in fluids [40].

For the relationship of $\mathrm{Cl}^{-}$vs. $\mathrm{SO}_{4}$ (Figure 9), a better correlation is observed for the Coconuco sector.

Considering the total ionic salinity (TIS) in Figure 10, for the Coconuco sector sources, a TIS between 0 and $25 \mathrm{mEq} / \mathrm{L}$ was observed and a TIS between 0 and $10 \mathrm{mEq} / \mathrm{L}$ was observed for the San Juan sector.

4.5. Mineralogical Characterization. In the analysis of X-ray diffractograms and according to the macroscopic description of the samples, it can be observed that the sample $\mathrm{CO} 2-\mathrm{A}$ is fine-grained sand, mainly composed of cristobalite, with high concentrations of iron oxides, which produces the reddish hue. Rock image and diffraction pattern of CO2-A are shown in Supplementary Materials (SS), figures 11a and 11b. Its 

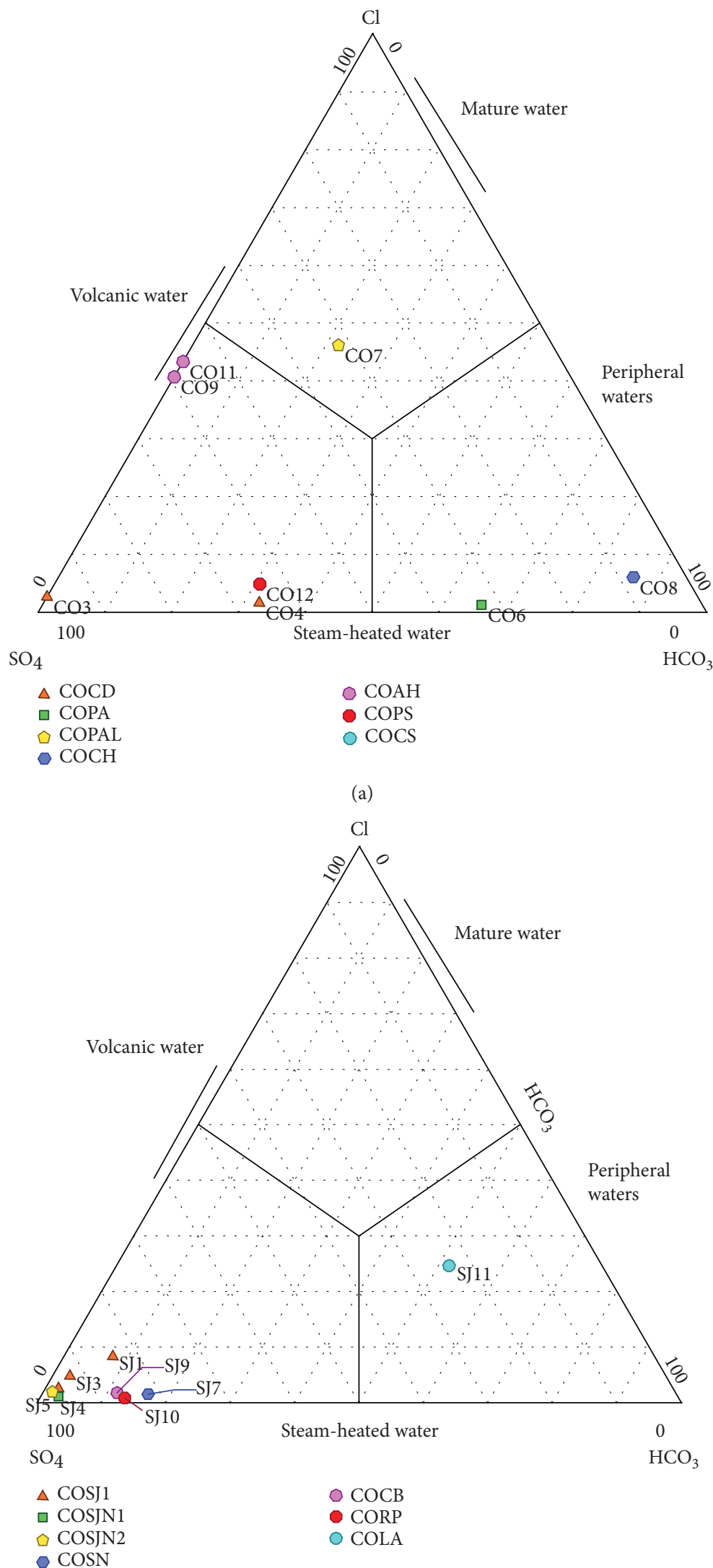

(b)

Figure 5: $\mathrm{Cl}^{-}-\left(\mathrm{SO}_{4}\right)^{2-}-\left(\mathrm{HCO}_{3}\right)^{-}$ternary diagram for the (a) Coconuco sector and the (b) San Juan sector [29]. 


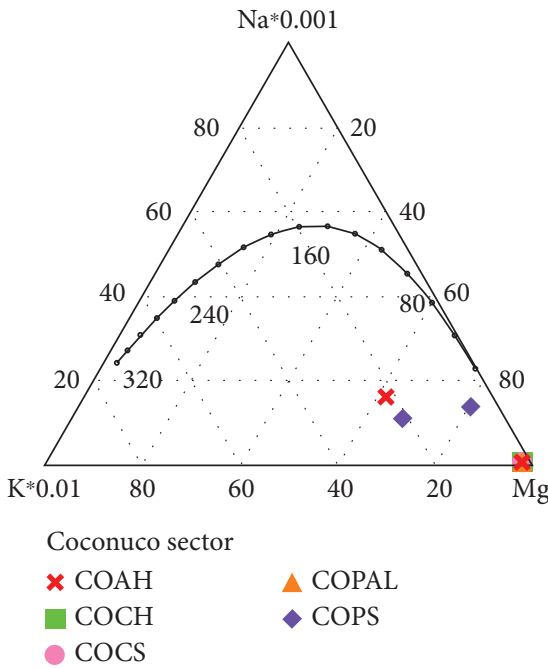

(a)

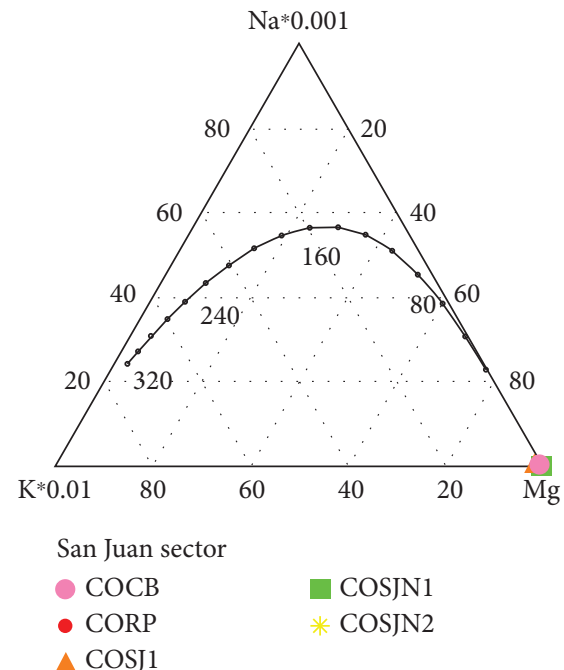

(b)

Figure 6: Ternary diagram of cations for the sources: (a) Coconuco sector and (b) San Juan sector [32].

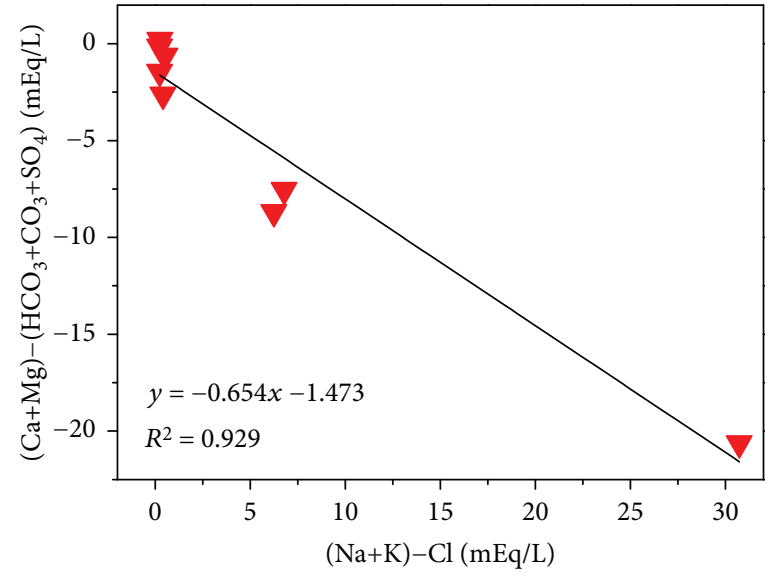

(a)

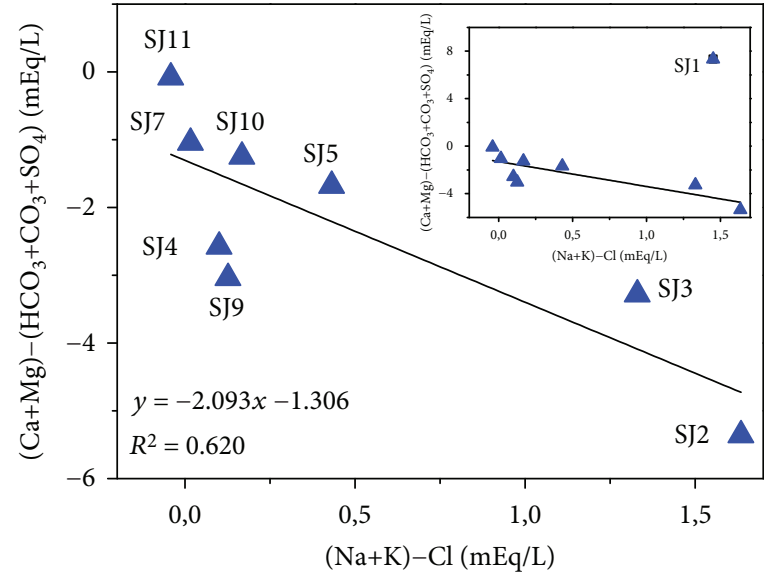

(b)

Figure 7: Relation between $\left(\mathrm{Na}^{+}+\mathrm{K}^{+}\right)-\mathrm{Cl}^{-}$and $\left(\mathrm{Ca}^{2+}+\mathrm{Mg}^{2+}\right)-\left(\left(\mathrm{HCO}_{3}\right)^{-}+\left(\mathrm{CO}_{3}\right)^{2-}+\left(\mathrm{SO}_{4}\right)^{2-}\right)$ on mEq/L: (a) Coconuco sector and (b) San Juan sector [37].

composition is mainly $\mathrm{SiO}_{2}, \mathrm{~K}^{+},\left(\mathrm{SO}_{4}\right)^{2-}, \mathrm{Al}$, and $\mathrm{Fe}$. The CO3-A sample (figures 12a and $12 \mathrm{~b}$ in SS) is characterized by high presence of sulfur $(\mathrm{S})$ in the form of $\left(\mathrm{SO}_{3}\right)$ and S-alpha. The CO11-A sample (figures 13a and 13b in SS) is quartzose sand with traces of titanomagnetite (golden color), hematite with muscovite, and oxidized biotites. This sand is a product of the weathering of the rocks that is found around the springs. The CO13-A sample (figures $14 \mathrm{a}$ and $14 \mathrm{~b}$ in SS) is a vitreous tufa with traces of sulfur and white gypsum rock with possible aluminum. The SJ1-A sample (figures 15b and 15a in SS) in the San Juan sector is a crystalline glass tufa; the SJ1-B sample (figures $16 \mathrm{~b}$ and $16 \mathrm{a}$ in SS) shows a classification of fine to very fine-grained sand composed of quartz (quartz isomorph cristobalite) and sulfur compounds; the SJ1-C sample (figures $17 \mathrm{a}$ and $17 \mathrm{~b}$ in
SS) has characteristics of being crystalline volcanic rock with traces of $\mathrm{TiO}_{2}$ and muscovite (bright gray). Finally, the SJ6-A sample (figures $18 \mathrm{a}$ and $18 \mathrm{~b}$ in SS) is crystalline glass tufa.

On the other hand, it is necessary to clarify that some diffraction patterns have a high amorphousness and representative variations although they coincide with the patterns of the database (shown in Table 5(b)).

The XRF analyses allow knowing the chemical composition of the samples in the form of oxides which are shown in Tables 6 and 7. The samples in general present higher percentages of primary minerals such as $\mathrm{SiO}_{2}, \mathrm{Al}_{2} \mathrm{O}_{3}$, and $\mathrm{SO}_{3}$. Additionally, the samples show a variety of their compositions and the presence of transition metals in very low concentrations is highlighted, including $\mathrm{Y}, \mathrm{W}, \mathrm{Nb}, \mathrm{V}$, $\mathrm{Zn}, \mathrm{Zr}$, and $\mathrm{Cr}$, among others. 


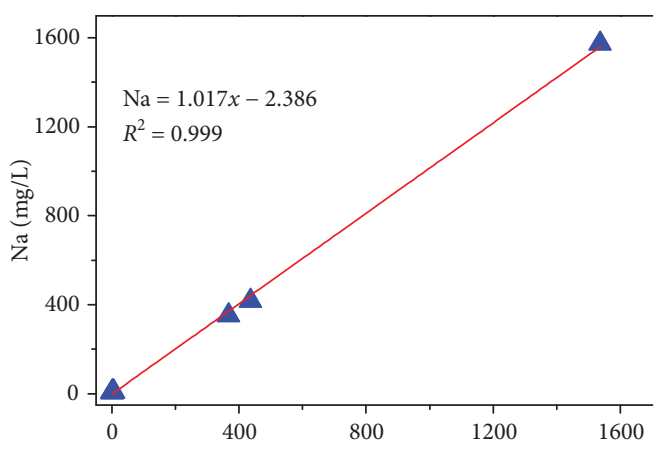

- $\mathrm{Na}$

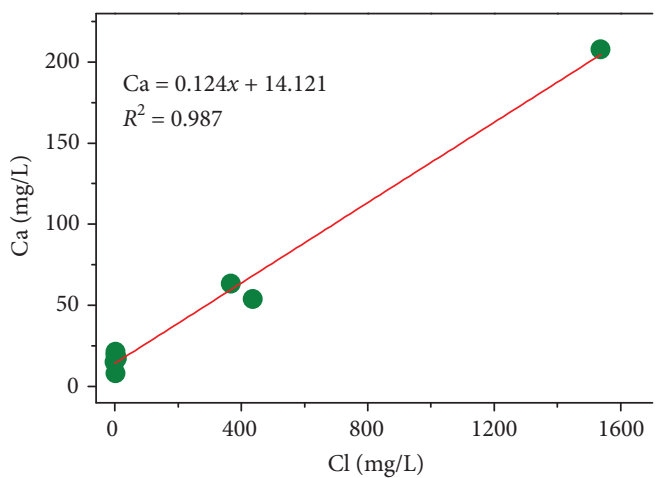

Ca

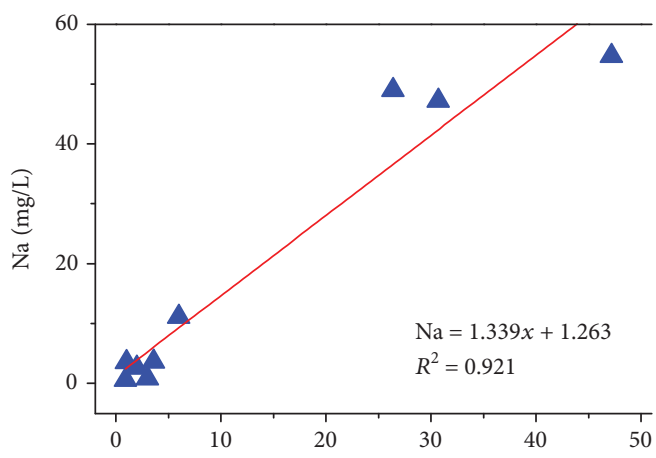

$\triangle \mathrm{Na}$

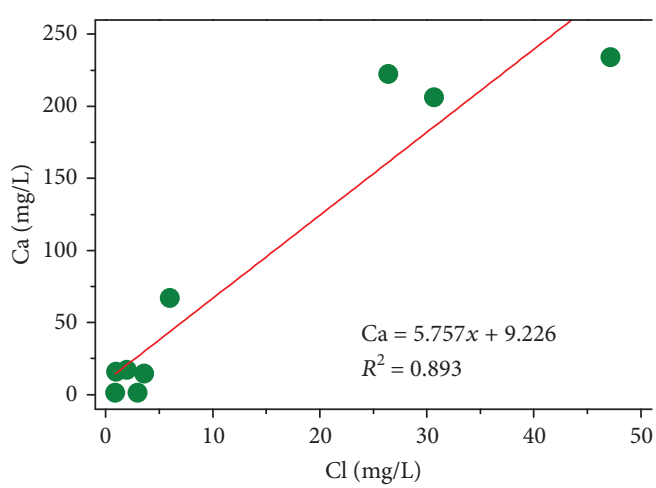

$\mathrm{Ca}$

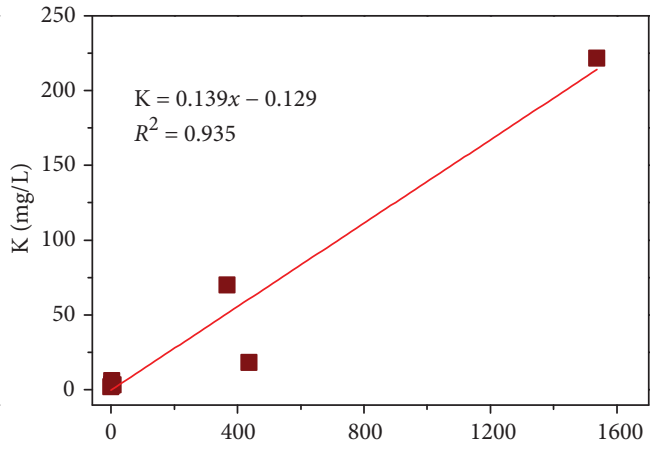

K

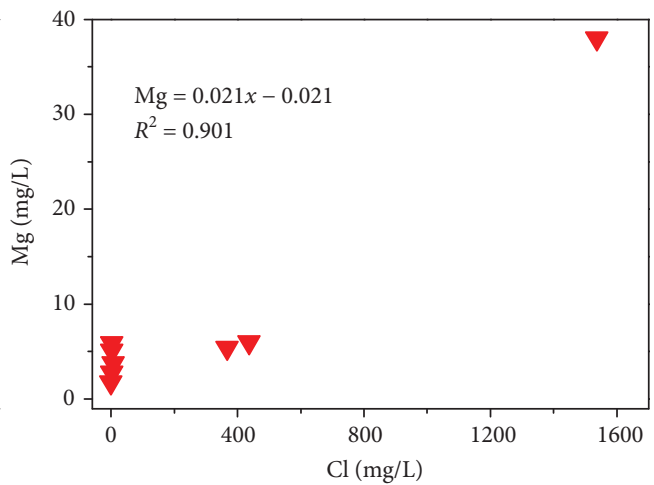

$\mathrm{Mg}$

(a)

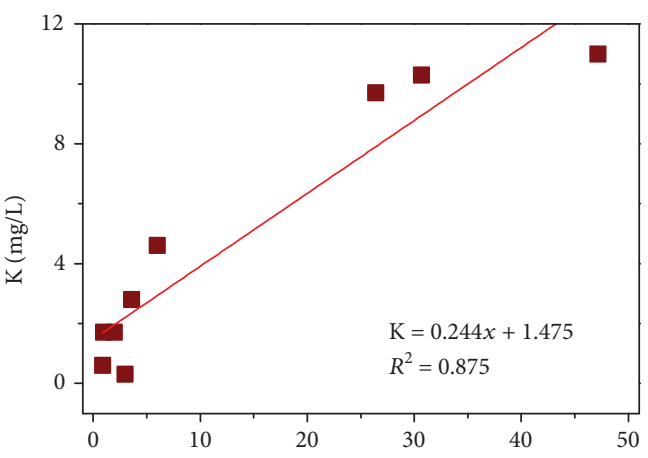

K

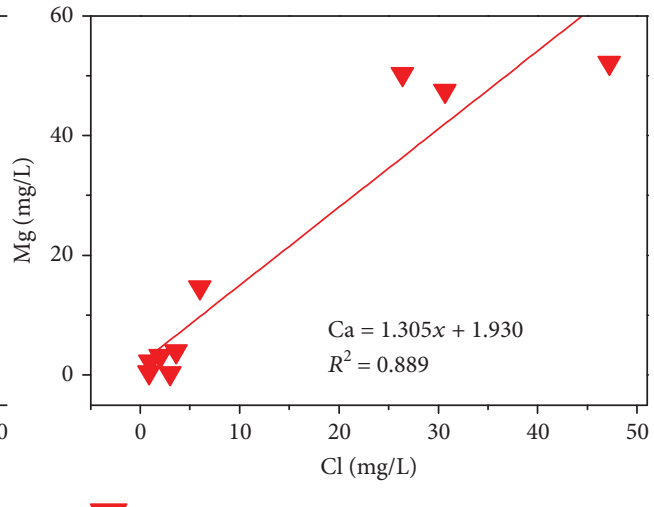

$\mathrm{Mg}$

(b)

Figure 8: Relation between $\mathrm{Cl}$ and $\mathrm{Na}, \mathrm{K}, \mathrm{Ca}$, and $\mathrm{Mg}$ : (a) Coconuco sector and (b) San Juan sector. 


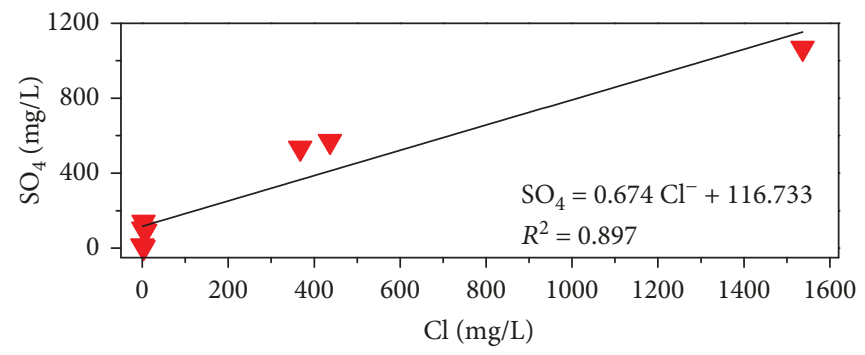

Coconuco sector

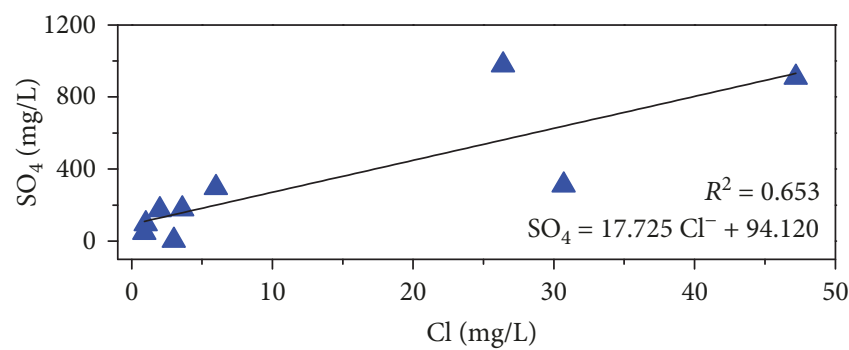

San Juan sector

FIgURE 9: Relation between $\mathrm{Cl}$ and $\mathrm{SO} 4$.

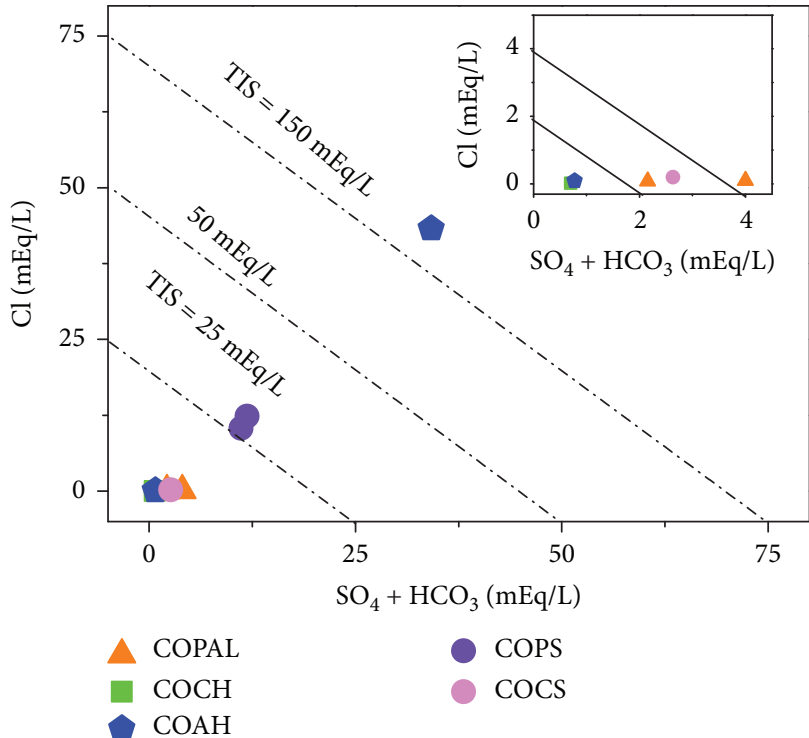

(a)

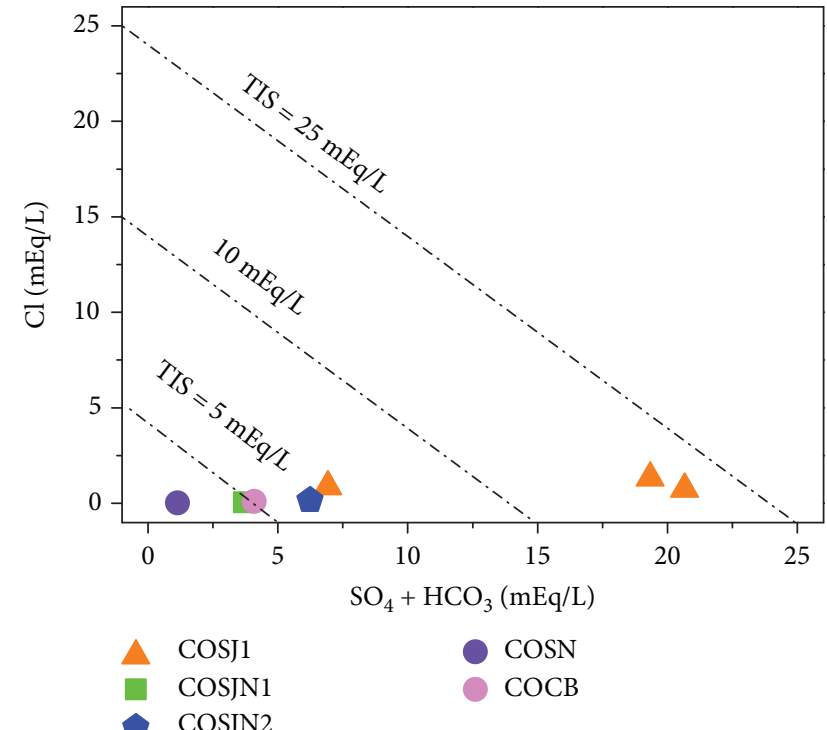

(b)

FIgure 10: Total ionic salinity (TIS) lines: (a) Coconuco sector and (b) San Juan sector.

\section{Discussion}

5.1. Thermal Water. Based on the above considerations, it was observed that most sources have a sulphated character, and, according to the literature, sulfur would be one of the main components of the thermal and volcanic fluids of the sectors studied. Regarding the above statement, it can be concluded that the rock-fluid interaction controls the sulfide concentrations in the fluids [2]. As mentioned, the sulfur present in volcanic geothermal fluids appears in both the liquid phase and the vapor phase, where the dissolved sulfide and sulphate are present in the liquid phase and sulfide is present in the vapor phase [1]. Regarding the sulphates, they are originated due to the mixture of surface water and magmatic vapor or steam condensation. In fact, such a vapor contains abundant volatile compounds of $\mathrm{H}_{2} \mathrm{~S}$ and $\mathrm{CO}_{2}$ which, when emerging through groundwater to the surface, produce the oxidation of $\mathrm{H}_{2} \mathrm{~S}$ to $\mathrm{H}_{2} \mathrm{SO}_{4}[5,6,15,41]$ (see equations (2) and (3)).

$$
\begin{gathered}
4 \mathrm{SO}_{2(\mathrm{ac})}+4 \mathrm{H}_{2} \mathrm{O}_{(1)} \leftrightarrow \mathrm{H}_{2} \mathrm{~S}_{(\mathrm{ac})}+3 \mathrm{H}_{2} \mathrm{SO}_{4(\mathrm{ac})} \\
\mathrm{H}_{2} \mathrm{~S}_{(\mathrm{ac})}+2 \mathrm{O}_{2(\mathrm{~g})} \leftrightarrow 2 \mathrm{H}_{(\mathrm{ac})}^{+}+\left(\mathrm{SO}_{4}\right)_{(\mathrm{ac})}^{2-}
\end{gathered}
$$


TABle 5: Analysis of quantification of minerals in samples from the (a) Coconuco sector and (b) San Juan sector.

(a)

\begin{tabular}{|c|c|c|c|c|c|}
\hline Minerals & Chemical formula & $\mathrm{CO} 2-\mathrm{A}$ & $\mathrm{CO} 3-\mathrm{A}$ & CO11-A & CO13-A \\
\hline Cristobalite & $\mathrm{SiO}_{2}$ & 34 & -- & -- & 100 \\
\hline Tridymite & $\mathrm{SiO}_{2}$ & 14 & -- & -- & -- \\
\hline Quartz & $\mathrm{SiO}_{2}$ & -- & 10.50 & -- & -- \\
\hline Albite & $\mathrm{NaAlSi}_{3} \mathrm{O}$ & -- & 11.98 & 80 & -- \\
\hline Sulfur & $S$ & -- & 77.92 & -- & -- \\
\hline Muscovite & $\mathrm{KAl}_{2}\left[\mathrm{AlSi}_{3}\right] \mathrm{O}_{10}(\mathrm{OH})_{2}$ & -- & -- & 7 & -- \\
\hline Hornblende & $\mathrm{Ca}_{2}(\mathrm{Mg}, \mathrm{Fe}, \mathrm{Al})_{2}-(\mathrm{Al}, \mathrm{Si})_{8} \mathrm{O}_{22}(\mathrm{OH})_{2}$ & -- & -- & 13 & -- \\
\hline Barite & $\mathrm{BaSO}_{4}$ & -- & 0.05 & -- & -- \\
\hline Alunite & $\mathrm{KAl}_{3}\left(\mathrm{SO}_{4}\right)_{2}(\mathrm{OH})_{6}$ & 37 & -- & -- & -- \\
\hline Hematite & $\mathrm{Fe}_{2} \mathrm{O}_{3}$ & 15 & -- & -- & -- \\
\hline
\end{tabular}

(b)

\begin{tabular}{lccccc}
\hline Minerals & Chemical formula & SJ1-A & SJ1-B & SJ1-C & SJ6-A \\
\hline Cristobalite & $\mathrm{SiO}_{2}$ & 100 & 25 & 91 \\
Sulfur & $\mathrm{S}$ & -- & 51 & -- & -- \\
Albite & $\mathrm{NaAlSi}_{3} \mathrm{O}$ & -- & 24 & -- & -- \\
Muscovite & $\mathrm{KAl}_{2}\left[\mathrm{AlSi}_{3}\right]_{10}(\mathrm{OH})_{2}$ & -- & -- & -- & 9 \\
\hline
\end{tabular}

Comparing the results obtained from SJ2 and SJ3 with the data shown in the National Inventory of Hydrothermal Manifestations report of the Colombian Geological Service obtained in 15/08/2012, variations of $\mathrm{pH}$ at approximately 0.5 , temperature at $\pm 2^{\circ} \mathrm{C}$, and decrease in conductivity were found.

Bearing in mind that in the area study which is located close to the Puracé volcano, the absorption of magmatic gas in the meteoric water occurs as a consequence of $\mathrm{S}$, generating waters of the sulphate acid type [15] as observed in previous publications [24]. The Coconuco sector that is located in the Caldera de Chagartón presents in its lithological section flows of ashes and andesitic lavas, among others, that can cause that the fluids suffer neutralization due to the hydrolysis of the rocks, producing water with more content in carbonates which generates steam-heated waters in the San Juan sector [15].

According to the ternary diagrams, the Coconuco and San Juan sectors present considerable concentrations of $\mathrm{SO}_{4}, \mathrm{Na}, \mathrm{Ca}$, and $\mathrm{HCO}_{3}$ which indicates the possibility of meteoric water circulating through the faults of the region and the exothermic reactions in the interior generate an increase in the temperature of the fluids [30]. On the other hand, the sources presented a classification of immaturity and the equilibrium clearly shifts towards $\mathrm{Mg}$, which means that the sources acquire $\mathrm{Mg}$ with the decrease in temperature [34]. Finally, it is important to note that elements that can be toxic such as $\mathrm{Cr}, \mathrm{Sr}$, and $\mathrm{Zn}$, among others, have low bioavailability due to their low concentrations in both water and rocks. This can be considered for future applications of thermal waters, either in the tourism industry, beekeeping, or others.
5.2. Minerals. Considering the results of XRD and XRF in the studied sectors, a high presence of $\mathrm{SiO}_{2}, \mathrm{Al}_{2} \mathrm{O}_{3}$, and $\mathrm{SO}_{3}$ compounds was observed in mineralogical phases such as cristobalite, sulfur, and albite. As for metals, some of these are found on the earth's crust as oxides in different oxidation states including vanadium oxide $\left(\mathrm{V}_{2} \mathrm{O}_{5}\right)$ (vanadium salts have low toxicity) and chromium ( $\mathrm{Cr}$ ) in chromite phase associated with iron $\left(\mathrm{FeCr}_{2} \mathrm{O}_{4}\right)$, and although its oxidation state depends on the $\mathrm{pH}$, it can be in $\mathrm{Cr}^{3+}$ or $\mathrm{Cr}^{6+}$, the latter being the most toxic form [42]. However, the amount present in the samples from the two sectors is lower than the average of $125 \mathrm{ppm}$ [43]. The $\mathrm{Zn}$ and $\mathrm{Cr}$ elements register values lower than the detection limit of the instruments $(<\mathrm{LDI})$ in water analysis (Table 3 ) and do not exceed $0.03 \%(w t)$ in the rocks.

Minerals such as albite and muscovite are composed of aluminum (Al). However, in the case of $\mathrm{Al}$, which is present in high concentrations in rocks, it stands out in the water analysis for its concentration <ILD (see Table 3(a)), since in the molecule of $\mathrm{Al}_{2} \mathrm{O}_{3}, \mathrm{Al}$ forms stable bonds with oxygen $\mathrm{O}_{2}$. Likewise, its mobility is relatively low when compared to elements such as $\mathrm{Cl}^{-}, \mathrm{Ca}^{2+}$, and $\mathrm{Na}^{+}$, which appear in higher concentrations. On the other hand, calcium, being slightly soluble, appears in considerable concentrations according to the water analysis, but in the XRD analysis, it is in the form of $\mathrm{CaO}$ in low concentrations.

Other elements or compounds such as iron $(\mathrm{Fe})$ and titanium (Ti), which may belong to the titanomagnetite mineral, are observed. Taking into account the SJ1 source with $\mathrm{pH}>5$ would not allow solubility of Fe as reported by Ramos et al. [44]. Likewise, Silva et al. [45] reported that iron is highly immobile at $\mathrm{pH}$ above 4.5 , which could be a 
TABLE 6: XRF analysis of Coconuco samples: (a) CO2-A. (b) CO3-A.

(c) CO11-A. and (d) CO13-A.

(a)

\begin{tabular}{lc}
\hline Element compound & wt (\%) \\
\hline $\mathrm{SiO}_{2}$ & 57,21 \\
$\mathrm{Fe}_{2} \mathrm{O}_{3}$ & 23,53 \\
$\mathrm{SO}_{3}$ & 8,73 \\
$\mathrm{Al}_{2} \mathrm{O}_{3}$ & 6,80 \\
$\mathrm{TiO}_{2}$ & 1,13 \\
$\mathrm{~K}_{2} \mathrm{O}$ & 1,00 \\
$\mathrm{P}_{2} \mathrm{O}_{5}$ & 0,60 \\
$\mathrm{Na}_{2} \mathrm{O}$ & 0,36 \\
$\mathrm{Ba}$ & 0,16 \\
$\mathrm{~V}$ & 0,12 \\
$\mathrm{CaO}$ & 0,09 \\
$\mathrm{Sr}$ & 0,07 \\
$\mathrm{Sb}$ & 0,05 \\
$\mathrm{MgO}$ & 0,04 \\
$\mathrm{Ce}$ & 0,04 \\
$\mathrm{~Pb}$ & 0,03 \\
$\mathrm{Cl}$ & 0,03 \\
$\mathrm{Cr}$ & 0,02 \\
$\mathrm{Zr}$ & 0,02 \\
$\mathrm{Nb}$ & $41 \mathrm{ppm}$ \\
$\mathrm{Y}$ & $21 \mathrm{ppm}$ \\
\hline
\end{tabular}

(b)

\begin{tabular}{lc}
\hline Element compound & wt (\%) \\
\hline $\mathrm{SO}_{3}$ & 54,68 \\
$\mathrm{SiO}_{2}$ & 39,93 \\
$\mathrm{Al}_{2} \mathrm{O}_{3}$ & 2,22 \\
$\mathrm{Fe}_{2} \mathrm{O}_{3}$ & 1,12 \\
$\mathrm{TiO}_{2}$ & 0,73 \\
$\mathrm{~K}_{2} \mathrm{O}$ & 0,35 \\
$\mathrm{CaO}$ & 0,32 \\
$\mathrm{Na}{ }_{2} \mathrm{O}$ & 0,26 \\
$\mathrm{MgO}$ & 0,16 \\
$\mathrm{P}_{2} \mathrm{O}_{5}$ & 0,09 \\
$\mathrm{Ba}$ & 0,07 \\
$\mathrm{Cr}$ & 0,03 \\
$\mathrm{Zr}$ & 0,02 \\
$\mathrm{MnO}$ & 0,02 \\
$\mathrm{~W}$ & 0,01 \\
$\mathrm{Sr}$ & $58 \mathrm{ppm}$ \\
$\mathrm{Nb}$ & $21 \mathrm{ppm}$ \\
\hline
\end{tabular}

(c)

\begin{tabular}{lc}
\hline Element compound & wt (\%) \\
\hline $\mathrm{SiO}_{2}$ & 55,74 \\
$\mathrm{Al}_{2} \mathrm{O}_{3}$ & 17,71 \\
$\mathrm{Fe}_{2} \mathrm{O}_{3}$ & 9,41 \\
$\mathrm{CaO}$ & 5,92 \\
$\mathrm{Na} \mathrm{O}_{2}$ & 3,78 \\
$\mathrm{MgO}$ & 3,07 \\
$\mathrm{~K}_{2} \mathrm{O}$ & 1,66 \\
$\mathrm{TiO}_{2}$ & 1,20 \\
$\mathrm{SO}_{3}$ & 0,74 \\
$\mathrm{MnO}_{2}$ & 0,19 \\
$\mathrm{P}_{2} \mathrm{O}_{5}$ & 0,16 \\
$\mathrm{Ba}$ & 0,11 \\
$\mathrm{Cl}$ & 0,08 \\
$\mathrm{Sr}$ & 0,08 \\
$\mathrm{Ce}$ & 0,03 \\
$\mathrm{Cr}$ & 0,03 \\
$\mathrm{Zr}$ & 0,02 \\
$\mathrm{~Pb}$ & 0,02 \\
$\mathrm{~V}$ & 0,02 \\
$\mathrm{~W}$ & 0,01 \\
$\mathrm{Zn}$ & 0,01 \\
$\mathrm{Nb}$ & 0,01 \\
$\mathrm{Rb}$ & $66 \mathrm{ppm}$ \\
$\mathrm{Y}$ & $34 \mathrm{ppm}$ \\
\hline
\end{tabular}

(d)

\begin{tabular}{lc}
\hline Element compound & wt (\%) \\
\hline $\mathrm{SiO}_{2}$ & 94,59 \\
$\mathrm{SO}_{3}$ & 2,86 \\
$\mathrm{TiO}_{2}$ & 0,79 \\
$\mathrm{Fe}_{2} \mathrm{O}_{3}$ & 0,75 \\
$\mathrm{Al}_{2} \mathrm{O}_{3}$ & 0,65 \\
$\mathrm{Ba}$ & 0,10 \\
$\mathrm{CaO}$ & 0,09 \\
$\mathrm{MgO}$ & 0,05 \\
$\mathrm{~K}$ & $\mathrm{O}$ \\
$\mathrm{MnO}$ & 0,04 \\
$\mathrm{Cr}$ & 0,02 \\
$\mathrm{Cl}$ & 0,02 \\
$\mathrm{Zr}$ & 0,01 \\
$\mathrm{Na}$ & 0,01 \\
$\mathrm{Nb}$ & $80 \mathrm{ppm}$ \\
$\mathrm{Sr}$ & $64 \mathrm{ppm}$ \\
\hline
\end{tabular}

problem in plants and produce necrosis in the leaves [44]. In this way, a relationship is established to justify that, although $\mathrm{Fe}$ is present in the rocks, it is not present in the waters, as 
TABLE 7: XRF analysis of San Juan samples: (a) SJ1-A. (b) SJ1-B. (c) SJ1-C. and (d) SJ6-A.

(a)

\begin{tabular}{lc}
\hline Element compound & wt (\%) \\
\hline $\mathrm{SiO}_{2}$ & 93,88 \\
$\mathrm{TiO}_{2}$ & 2,43 \\
$\mathrm{SO}_{3}$ & 1,80 \\
$\mathrm{Al}_{2} \mathrm{O}_{3}$ & 0,92 \\
$\mathrm{Na}_{2} \mathrm{O}$ & 0,25 \\
$\mathrm{Fe}_{2} \mathrm{O}_{3}$ & 0,21 \\
$\mathrm{CaO}_{2}$ & 0,19 \\
$\mathrm{P}_{2} \mathrm{O}_{5}$ & 0,11 \\
$\mathrm{MgO}$ & 0,08 \\
$\mathrm{~K}_{2} \mathrm{O}$ & 0,05 \\
$\mathrm{Zr}$ & 0,04 \\
$\mathrm{Cl}$ & 0,02 \\
$\mathrm{Cr}$ & 0,02 \\
$\mathrm{~W}$ & 0,01 \\
$\mathrm{Nb}$ & $44 \mathrm{ppm}$ \\
$\mathrm{Sr}$ & $38 \mathrm{ppm}$ \\
\hline
\end{tabular}

(b)

\begin{tabular}{lc}
\hline Element compound & wt (\%) \\
\hline $\mathrm{SiO}_{2}$ & 55,79 \\
$\mathrm{SO}_{3}$ & 35,4 \\
$\mathrm{Al}_{2} \mathrm{O}_{3}$ & 3,98 \\
$\mathrm{~K}_{2} \mathrm{O}$ & 1,22 \\
$\mathrm{Fe}_{2} \mathrm{O}_{3}$ & 1,18 \\
$\mathrm{TiO}_{2}$ & 0,74 \\
$\mathrm{Na}_{2} \mathrm{O}$ & 0,63 \\
$\mathrm{CaO}$ & 0,61 \\
$\mathrm{MgO}$ & 0,17 \\
$\mathrm{Ba}$ & 0,08 \\
$\mathrm{P}_{2} \mathrm{O}_{5}$ & 0,07 \\
$\mathrm{Cl}$ & 0,05 \\
$\mathrm{MnO}$ & 0,02 \\
$\mathrm{Zr}$ & 0,02 \\
$\mathrm{Sr}$ & 0,01 \\
$\mathrm{Cr}$ & $74 \mathrm{ppm}$ \\
$\mathrm{Rb}$ & $73 \mathrm{ppm}$ \\
$\mathrm{Pb}$ & $58 \mathrm{ppm}$ \\
$\mathrm{Nb}$ & $51 \mathrm{ppm}$ \\
$\mathrm{Cu}$ & $39 \mathrm{ppm}$ \\
$\mathrm{Y}$ & $10 \mathrm{ppm}$ \\
\hline
\end{tabular}

(c)

\begin{tabular}{lc}
\hline Element compound & wt (\%) \\
\hline $\mathrm{SiO}_{2}$ & 89,09 \\
$\mathrm{Al}_{2} \mathrm{O}_{3}$ & 4,41 \\
\hline
\end{tabular}

TABle 7: Continued.

\begin{tabular}{lc}
\hline Element compound & wt $(\%)$ \\
\hline $\mathrm{K}_{2} \mathrm{O}$ & 1,82 \\
$\mathrm{TiO}_{2}$ & 1,73 \\
$\mathrm{SO}_{3}$ & 1,31 \\
$\mathrm{Fe}_{2} \mathrm{O}_{3}$ & 0,77 \\
$\mathrm{CaO}$ & 0,28 \\
$\mathrm{Na}_{2} \mathrm{O}$ & 0,17 \\
$\mathrm{Cl}$ & 0,11 \\
$\mathrm{MgO}$ & 0,07 \\
$\mathrm{P}_{2} \mathrm{O}_{5}$ & 0,07 \\
$\mathrm{Ba}$ & 0,07 \\
$\mathrm{Zr}$ & 0,04 \\
$\mathrm{MnO}$ & 0,02 \\
$\mathrm{Rb}$ & 0,01 \\
$\mathrm{Ce}$ & 0,01 \\
$\mathrm{Cr}$ & $80 \mathrm{ppm}$ \\
$\mathrm{Nb}$ & $70 \mathrm{ppm}$ \\
$\mathrm{Sr}$ & $34 \mathrm{ppm}$ \\
$\mathrm{Zn}$ & $28 \mathrm{ppm}$ \\
$\mathrm{Y}$ & $10 \mathrm{ppm}$ \\
\hline
\end{tabular}

(d)

\begin{tabular}{lc}
\hline Element compound & wt $(\%)$ \\
\hline $\mathrm{SiO}_{2}$ & 94,58 \\
$\mathrm{TiO}_{2}$ & 2,65 \\
$\mathrm{Al}_{2} \mathrm{O}_{3}$ & 1,05 \\
$\mathrm{SO}_{3}$ & 0,94 \\
$\mathrm{Fe}_{2} \mathrm{O}_{3}$ & 0,28 \\
$\mathrm{Na}_{2} \mathrm{O}$ & 0,17 \\
$\mathrm{CaO}$ & 0,13 \\
$\mathrm{P}_{2} \mathrm{O}_{5}$ & 0,06 \\
$\mathrm{MgO}$ & 0,05 \\
$\mathrm{~K}_{2} \mathrm{O}$ & 0,04 \\
$\mathrm{Zr}$ & 0,03 \\
$\mathrm{Cr}$ & 0,01 \\
$\mathrm{Nb}$ & $69 \mathrm{ppm}$ \\
$\mathrm{Sr}$ & $28 \mathrm{ppm}$ \\
\hline
\end{tabular}

shown in Table 3(a). Ti was not considered for the water analysis in this study.

\section{Conclusion}

Physical-chemical characterization was carried out for 9 water sources in San Juan (Cauca, Colombia, South America). It was found that these sources are of sulphated acid type, with $\mathrm{pH}$ between 5 and 8. Additionally, it was observed that, despite the interaction with rocks, these sources are not in chemical equilibrium with rocks, resulting in immature water of the heated vapor type. Because of the sulphated acid 
type of the waters, it was not possible to calculate the reservoir temperature with the $\mathrm{Na} / \mathrm{K}$ ratio.

Low $\mathrm{Ca}^{2+} / \mathrm{Mg}^{2+}$ ratio indicates that the direct migration of fluids is not possible and, apparently, they are mixed with cold waters rich in $\mathrm{Ca}^{2+}$ and $\mathrm{Mg}^{2+}$, due to the high content of these cations in comparison with $\mathrm{Na}^{+}$and $\mathrm{K}^{+}$cations. In addition, the lack or low concentration of metals like $\mathrm{Cr}$, $\mathrm{Zn}, \mathrm{Fe}$, and $\mathrm{Al}$ in waters stands out although $\mathrm{Al}$ and $\mathrm{Fe}$ are present in the rock samples.

Binary relations ( $\mathrm{Cl}$ vs. cations) presented a linear behavior with a determination coefficient of $R^{2}$ between 0.901 and 0.999 in the Coconuco sector and between 0.875 and 0.921 in the San Juan sector.

The mineralogic study by means of XRF and XRD showed that volcanic rocks are composed of minerals like cristobalite, albite, and sulfur, and in oxide composition of these rock samples, the presence of $\mathrm{SiO}_{2}, \mathrm{Al}_{2} \mathrm{O}_{3}, \mathrm{TiO}_{2}$, $\mathrm{Fe}_{2} \mathrm{O}_{3}$, and $\mathrm{CaO}$ is highlighted. Elements like $\mathrm{Al}$ and $\mathrm{Fe}$, although present in rocks, were not found in the waters, since temperatures and $\mathrm{pH}$ of the sources did not favor lixiviation processes.

\section{Data Availability}

The data used to support the findings of this study are included within the article. However, any additional information that is required may be acquired from the corresponding author upon request.

\section{Conflicts of Interest}

The authors declare that they have no competing interests.

\section{Acknowledgments}

The authors are grateful for the financial support of the Dirección Nacional de Investigaciones at Universidad Nacional de Colombia, in the framework of the project for the development of a technological environment, Termacolores, in the Puracé Ethnic Group Reservation (PEGR) for research and innovation in the use of hot springs and mineral waters and use of natural sulfur aimed at promoting tourism and well-being in the Department of Cauca "Desarrollo de un entorno tecnológico Termacolores en el resguardo indígena Puracé para la investigación e innovación en el uso de aguas termales, aguas minerales y aprovechamiento del azufre natural orientados a potenciar el turismo y bienestar en el Departamento del Cauca."

\section{Supplementary Materials}

Figure 11: sample CO2-A: (a) XRD patterns and (b) rock sample of cristobalite. Figure 12: sample CO3-A: (a) XRD patterns and (b) rock photo. Figure 13: sample CO11-A: (a) XRD patterns and (b) sand rock. Figure 14: sample CO13-A: (a) XRD patterns and (b) glassy tuff. Figure 15: sample SJ1-A (a) XRD patterns and (b) rock sample of crystalline tuff. Figure 16: sample SJ1-B: (a) XRD patterns and (b) quartz isomorph cristobalite. Figure 17: sample
SJ1-C: (a) XRD patterns and (b) crystalline volcanic rock. Figure 18: sample SJ6-A: (a) XRD patterns and (b) rock sample of crystalline tuff. (Supplementary Materials)

\section{References}

[1] A. Stefánsson, N. S. Keller, J. G. Robin, and S. Ono, "Multiple sulfur isotope systematics of Icelandic geothermal fluids and the source and reactions of sulfur in volcanic geothermal systems at divergent plate boundaries," Geochimica et Cosmochimica Acta, vol. 165, pp. 307-323, 2015.

[2] J. Gunnarsson-Robin, A. Stefánsson, S. Ono, and P. Torssander, "Sulfur isotopes in Icelandic thermal fluids," Journal of Volcanology and Geothermal Research, vol. 346, pp. 161179, 2017.

[3] D. Chandrasekharam and J. Bundschuh, Low-Enthalpy Geothermal Resources for Power Generation, CRC Press, London, UK, 2008.

[4] H. Ben Dhia and N. Meddeb, "Application of chemical geothermometers to some Tunisian hot springs," Geothermics, vol. 19, no. 1, pp. 87-104, 1990.

[5] J. K. Bjorke, A. Stefánsson, and S. Arnórsson, "Surface water chemistry at Torfajökull, Iceland-quantification of boiling, mixing, oxidation and water-rock interaction and reconstruction of reservoir fluid composition," Geothermics, vol. 58, pp. 75-86, 2015.

[6] J. Wrage, D. Tardani, M. Reich et al., "Geochemistry of thermal waters in the Southern Volcanic Zone, Chile: implications for structural controls on geothermal fluid composition," Chemical Geology, vol. 466, pp. 545-561, 2017.

[7] Y. A. Abdulkadir and T. H. Eritro, "2D resistivity imaging and magnetic survey for characterization of thermal springs: a case study of Gergedi thermal springs in the northwest of Wonji, Main Ethiopian Rift, Ethiopia," Journal of African Earth Sciences, vol. 133, pp. 95-103, 2017.

[8] S. Borović and I. Marković, "Utilization and tourism valorisation of geothermal waters in Croatia," Renewable and Sustainable Energy Reviews, vol. 44, pp. 52-63, 2015.

[9] N. Watts-Henwood, K. A. Campbell, B. Y. Lynne, D. M. Guido, J. V. Rowland, and P. R. L. Browne, "Snapshot of hotspring sinter at Geyser Valley, Wairakei, New Zealand, following anthropogenic drawdown of the geothermal reservoir," Geothermics, vol. 68, pp. 94-114, 2017.

[10] S. A. King, S. Behnke, K. Slack et al., "Mercury in water and biomass of microbial communities in hot springs of Yellowstone National Park, USA," Applied Geochemistry, vol. 21, no. 11, pp. 1868-1879, 2006.

[11] K. Bucher, L. Zhang, and I. Stober, "A hot spring in granite of the Western Tianshan, China," Applied Geochemistry, vol. 24, no. 3, pp. 402-410, 2009.

[12] A. Cox, E. L. Shock, and J. R. Havig, "The transition to microbial photosynthesis in hot spring ecosystems," Chemical Geology, vol. 280, no. 3-4, pp. 344-351, 2011.

[13] R. Chandrajith, J. A. C. Barth, N. D. Subasinghe, D. Merten, and C. B. Dissanayake, "Geochemical and isotope characterization of geothermal spring waters in Sri Lanka: evidence for steeper than expected geothermal gradients," Journal of Hydrology, vol. 476, pp. 360-369, 2013.

[14] M. O. Awaleh, F. B. Hoch, I. H. Kadieh et al., "The geothermal resources of the Republic of Djibouti I hydrogeochemistry 
of the Obock coastal hot springs," Journal of Geochemical Exploration, vol. 152, pp. 54-66, 2015.

[15] N. C. Sturchio, S. N. Williams, and Y. Sano, "The hydrothermal system of Volcan Puracé, Colombia," Bulletin of Volcanology, vol. 55, no. 4, pp. 289-296, 1993.

[16] T. P. Fischer, N. C. Sturchio, J. Stix, G. B. Arehart, D. Counce, and S. N. Williams, "The chemical and isotopic composition of fumarolic gases and spring discharges from Galeras Volcano, Colombia," Journal of Volcanology and Geothermal Research, vol. 77, no. 1-4, pp. 229-253, 1997.

[17] G. Garzón, "Catalogo de fuentes termales del suroccidente Colombiano," Tech. Rep., INGEOMINAS, 1997.

[18] S. Inguaggiato, J. M. Londoño, Z. Chacón, M. Liotta, E. Gil, and D. Alzate, "The hydrothermal system of Cerro Machín volcano (Colombia): new magmatic signals observed during 2011-2013," Chemical Geology, vol. 469, pp. 60-68, 2017.

[19] M. M. Parks, J. Biggs, T. A. Mather et al., "Co-eruptive subsidence at Galeras identified during an InSAR survey of Colombian volcanoes (2006-2009)," Journal of Volcanology and Geothermal Research, vol. 202, no. 3-4, pp. 228-240, 2011.

[20] E. Lozano, "Hot springs and geothermal energy in Colombia," Geothermics, vol. 17, no. 2-3, pp. 377-379, 1988.

[21] W. D. Pennington, "Subduction of the Eastern Panama Basin and seismotectonics of Northwestern South America," Journal of Geophysical Research, vol. 86, no. B11, pp. 1075310770, 1981.

[22] M. L. Monsalve and B. Pulgarín, "Cadena volcánica de los Coconucos (Colombia) centros eruptivos y productos recientes," Boletín Geológico, vol. 37, no. 1-3, 1999.

[23] A. P. Acevedo, M. L. Monsalve, and H. Cepeda, "Petrografía de algunas lavas de la cadena Coconuco. Informe interno," Tech. Rep., INGEOMINAS, 1987.

[24] D. A. Torres-Ceron, C. D. Acosta-Medina, and E. RestrepoParra, "Geothermal and mineralogic analysis of hot springs in the Puracé-La Mina sector in Cauca, Colombia," Geofluids, vol. 2019, Article ID 3191454, 20 pages, 2019.

[25] E. W. Rice, R. B. Baird, A. D. Eaton, and L. S. Clesceri, Eds., Standard Methods for the Examination of Water and Wastewater, APHA, 22nd edition, 1998, https://store.awwa.org/ store/productdetail.aspx? productid $=28493774$.

[26] A. X. S. Bruker, EVA, Software, Karlsruhe, Germany, 2001.

[27] A. Coelho, TOPAS Academic v4.1, Coelho Software, Brisbane, Australia, 2007.

[28] D. Kirk Nordstrom, R. Blaine McCleskey, and J. W. Ball, "Sulfur geochemistry of hydrothermal waters in Yellowstone National Park: IV acid-sulfate waters," Applied Geochemistry, vol. 24, no. 2, pp. 191-207, 2009.

[29] W. F. Giggenbach, "Geothermal solute equilibria. Derivation of Na-K-Mg-Ca geoindicators," Geochimica et Cosmochimica Acta, vol. 52, no. 12, pp. 2749-2765, 1988.

[30] H. Mohammadzadeh and M. Kazemi, "Geofluids assessment of the Ayub and Shafa hot springs in Kopet-Dagh Zone (NE Iran): an isotopic geochemistry approach," Geofluids, vol. 2017, Article ID 6358680, 11 pages, 2017.

[31] G. Marquinez, Y. Rodriguez, and J. Fuquen, "Mapa geológico de Colombia Plancha 365 Coconuco," Tech. Rep., INGEOMINAS, 2003.

[32] W. F. Giggenbach, "Graphical techniques for the evaluation of water/rock equilibration conditions by use of $\mathrm{Na}, \mathrm{K}, \mathrm{Mg}$ and Ca contents of discharge waters," in Proceedings of the 8th New Zealand Geothermal Workshop, pp. 37-43, Auckland,
New Zealand, 1986, https://www.geothermal-energy.org/pdf/ IGAstandard/NZGW/1986/Giggenbach.pdf.

[33] R. Fournier, "Application of water geochemistry to geothermal exploration and reservoir engineering," in Geothermal Systems: Principles and Case Histories, L. Rybach and L. J. P. Muffler, Eds., pp. 109-143, John Wiley \& Sons, 1981.

[34] X. Wang, G. L. Wang, H. N. Gan, Z. Liu, and D. W. Nan, "Hydrochemical characteristics and evolution of geothermal fluids in the Chabu high-temperature geothermal system, Southern Tibet," Geofluids, vol. 2018, Article ID 8532840, 15 pages, 2018.

[35] Y. Liu, X. Zhou, Z. Deng et al., "Hydrochemical characteristics and genesis analysis of the Jifei hot spring in Yunnan, southwestern China," Geothermics, vol. 53, pp. 38-45, 2015.

[36] N. Majumdar, A. L. Mukherjee, and R. K. Majumdar, "Mixing hydrology and chemical equilibria in Bakreswar geothermal area, Eastern India," Journal of Volcanology and Geothermal Research, vol. 183, no. 3-4, pp. 201-212, 2009.

[37] Y. Hou, Z. Shi, and W. Mu, "Fluid geochemistry of fault zone hydrothermal system in the Yidun-Litang area, eastern Tibetan Plateau geothermal belt," Geofluids, vol. 2018, Article ID 6872563, 13 pages, 2018.

[38] C. Apollaro, G. Vespasiano, R. De Rosa, and L. Marini, "Use of mean residence time and flowrate of thermal waters to evaluate the volume of reservoir water contributing to the natural discharge and the related geothermal reservoir volume. Application to Northern Thailand hot springs," Geothermics, vol. 58, pp. 62-74, 2015.

[39] D. Elissavet and C. Paraskevi, “Thermal water's isotope geochemistry study of Evros area, NE Greece," IOP Conference Series: Earth and Environmental Science, vol. 44, no. 5, article 052035, 2016.

[40] F. Bahri, H. Saibi, and M.-E.-H. Cherchali, "Characterization, classification, and determination of drinkability of some Algerian thermal waters," Arabian Journal of Geosciences, vol. 4, no. 1-2, pp. 207-219, 2011.

[41] H. Kaasalainen and A. Stefánsson, "The chemistry of trace elements in surface geothermal waters and steam, Iceland," Chemical Geology, vol. 330-331, pp. 60-85, 2012.

[42] Z. Yao, F. Jia, Y. Jiang, C. Li, Z. Jiang, and X. Bai, "Photocatalytic reduction of potassium chromate by $\mathrm{Zn}$-doped $\mathrm{TiO}_{2} / \mathrm{Ti}$ film catalyst," Applied Surface Science, vol. 256, no. 6, pp. 1793-1797, 2010.

[43] T. V. Sepulveda, J. A. V. Trejo, and D. A. D. L. R. Pérez, "Suelos contaminados por metales y metaloides: muestreo y alternativas para su remediación," Secretaría de Medio Ambiente y Recursos Naturales Instituto Nacional de Ecología, México, D.F., 1st edition, 2005.

[44] C. G. Ramos, X. Querol, M. L. S. Oliveira, K. Pires, R. M. Kautzmann, and L. F. S. Oliveira, "A preliminary evaluation of volcanic rock powder for application in agriculture as soil a remineralizer," Science of the Total Environment, vol. 512513, pp. 371-380, 2015.

[45] L. F. O. Silva, M. Izquierdo, X. Querol et al., "Leaching of potential hazardous elements of coal cleaning rejects," Environmental Monitoring and Assessment, vol. 175, no. 1-4, pp. 109-126, 2011. 

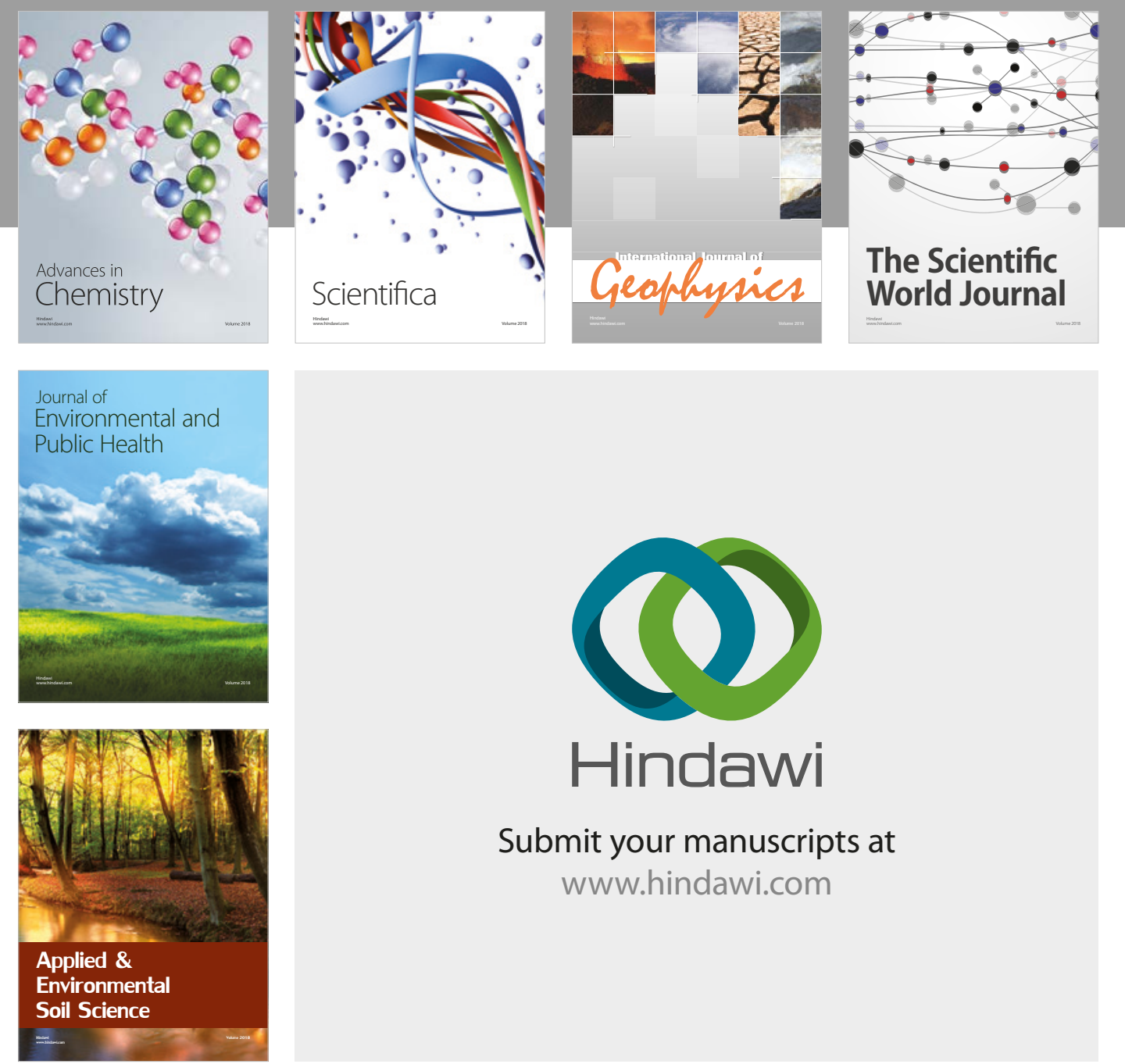

The Scientific

\section{World Journal}
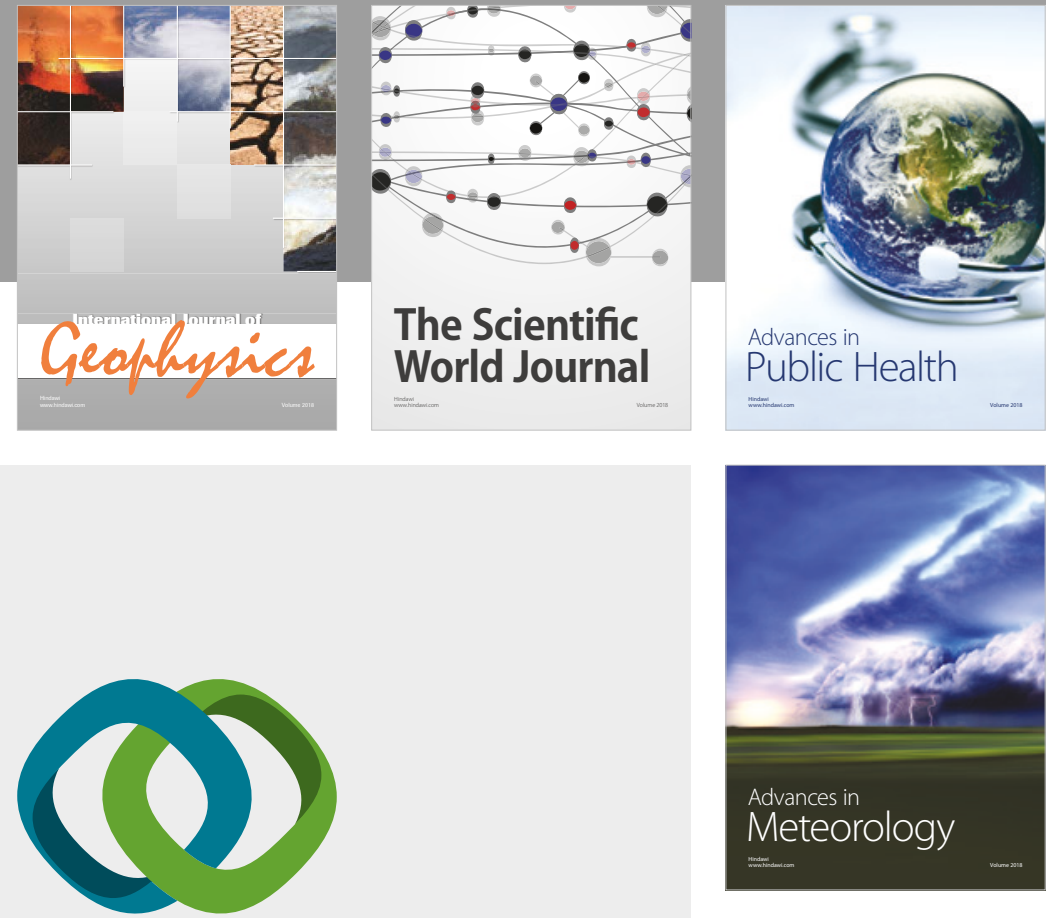

Advan

Public Health

\section{Hindawi}

Submit your manuscripts at

www.hindawi.com
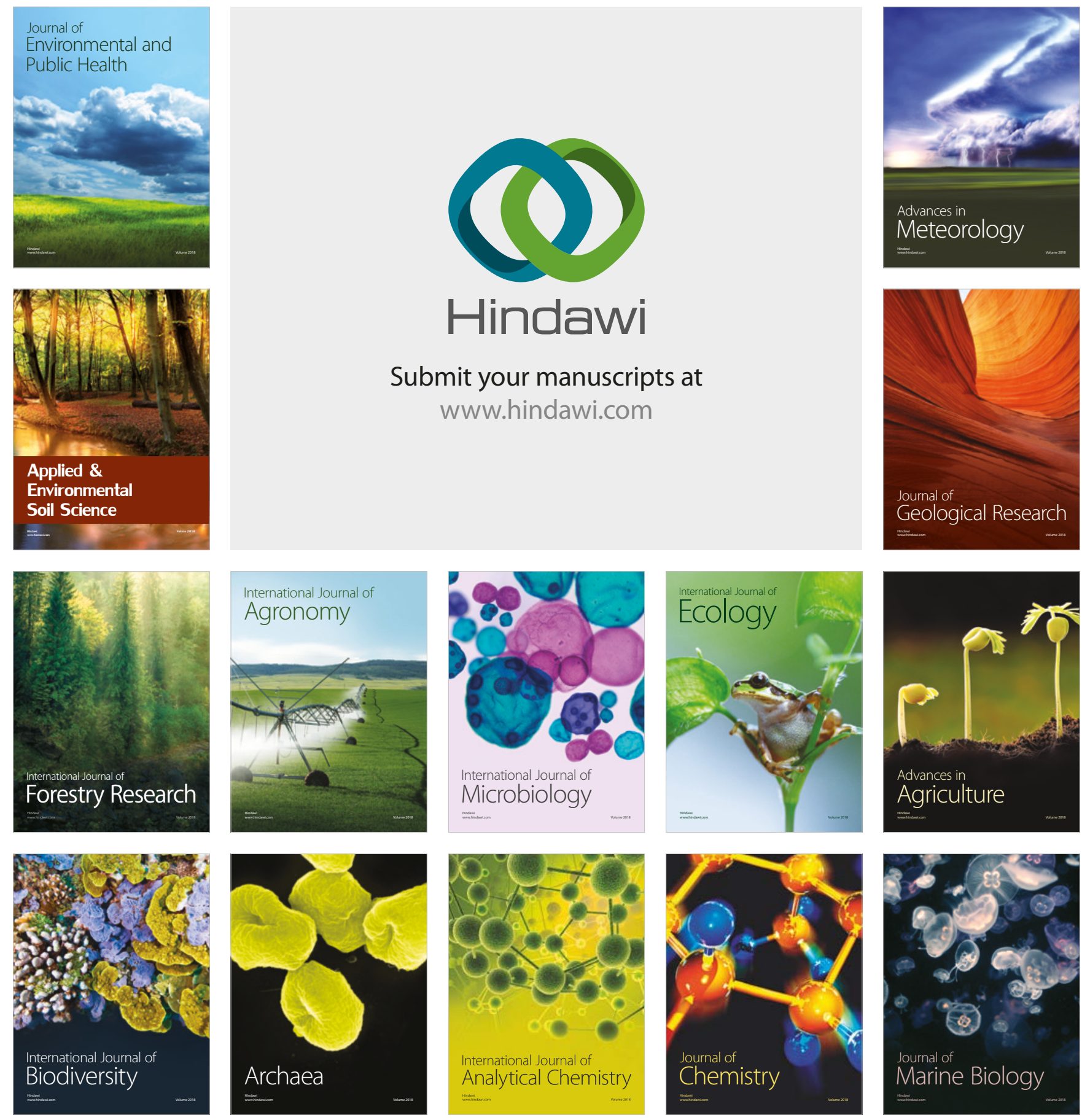